Trakya Eğitim Dergisi

Cilt 9, Sayı 3

Eylül 2019, 415-436

Gelis Tarihi: 17.08.2018

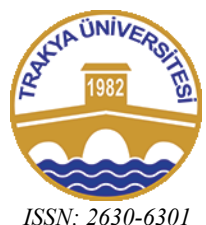

ISSN: 2630-6301
Trakya Journal of Education

Volume 9, Issue 3

September 2019, 415-436

\title{
Renk Kodları ile Direnç Okumanın Öğretiminde Simülasyon Kullanımının Öğrenme Üzerindeki Etkisi ve Öğrencilerin Görüşşleri
}

\section{Effect of Using Simulation on the Teaching of Resistance Reading with Color Codes on Learning and Students' Opinions}

\author{
Gonca HARMAN ${ }^{1}$, Nisa YENIKKALAYCI ${ }^{2}$
}

\begin{abstract}
Öz: Bu araştırmada renk kodları ile direnç okumanın öğretiminde simülasyon kullanımının öğrenme üzerindeki etkisi ve öğrencilerin görüşleri incelenmiştir. Araştırmaya Fen Bilgisi Eğitimi Anabilim Dalı birinci sınıfta öğrenim gören 60 öğrenci katılmıştır. Araştırmada tek örneklem son test desen kullanılmıştır. 10 sorudan oluşan başarı testi ve başarı testine ilave edilen 2 açık uçlu soru kullanılarak veriler toplanmıştır. Araştırma sonucunda renk kodları ile direnç okumanın öğretiminde simülasyon kullanımının öğrenme üzerinde etkili olduğu saptanmıştır. Fen bilgisi öğrencilerinin simülasyon kullanımına yönelik görüşlerinin genel olarak olumlu olduğu belirlenmiştir. Öğrencilerin simülasyon kullanımının avantajlarına yönelik görüşlerinin "akılda kalıcılık, pratik yapma, görsel, eğlenceli, kolay ve anlamlı ögrenme, hızlı öğrenme, zamandan tasarruf sağlama, pratik kullanım, direnç okumada kolaylık sağlama”; dezavantajlarına yönelik görüşlerinin ise "kafa karıştırması, gerçeğini görme isteği, ezber gerektirmesi, uğraştırıcı olması ve uzun zaman alması" kodlarında yoğunlaştığı belirlenmiştir.
\end{abstract}

Anahtar sözcükler: Simülasyon, renk kodları, direnç okuma, fen bilgisi ögrencisi

\begin{abstract}
In this study, effect of using simulation on the teaching of resistance reading with color codes on learning, and students' opinions were examined. The study was conducted with the participation of 60 first-year students attending the Science Education Department. One sample post-test design was used in the study. Data was collected by using achievement test including 10 questions and 2 open-ended questions added to achievement test. As a result of this study, it was reached that using simulation on the teaching of resistance reading with color codes is effective on learning. It was determined that students' opinions on using simulation are positive in general. It was determined that students' opinions on advantages of using simulation centered on codes of "memorable, practical, visual, enjoyable, easy and meaningful learning, time saving, practical usage, making resistance reading easier" and that students' opinions on disadvantages of using simulation mainly focused on codes of "being confusing, desire to see the real one, requiring memorization, being challenging and taking long time".
\end{abstract}

Keywords: Simulation, color codes, resistance reading, science student

\section{EXTENDED ABSTRACT}

\section{Introduction}

Electric circuit is one of the main subjects of the units related to electric which is included in all grades of science and physics training. Electric circuit, in the simplest sense, is formed by connecting components such as "resistance, key, power supply..." etc. with connection wires. Students often encounter with "resistances" which are one of the circuit components at the training period of science and physics courses. Symbolic representation which is visualized by the students whenever "resistance" is mentioned may be similar because of classical resistances and their figures which students encounter.

It isn't possible to include resistance, represented to the students in laboratory environment, into electrically operated instruments and internal structures of the electronic instruments. For that reason, circuit systems are established by placing small resistances with color codes, namely small structures having bands with different colors, into internal structures of these instruments. The value of resistance varies by color values of the bands over them. The simplest way to indicate value of the resistance by reading these values is to use applications which allow students to choose any band with any color and practice with a large number of samples. These applications appear as simulations.

In this study, effect of using simulation on the teaching of resistance reading with color codes on learning, and students' opinions were examined.

\footnotetext{
${ }^{1}$ Dr. Öğr. Üyesi, Karamanoğlu Mehmetbey Üniversitesi, Eğitim Fakültesi, Matematik ve Fen Bilimleri Eğitimi Bölümü, Fen Bilgisi Eğitimi Anabilim Dalı, e-posta: goncaharman@kmu.edu.tr, ORCID: 0000-0002-9717-1150

${ }^{2}$ Arş. Gör., Ondokuz Mayıs Üniversitesi, Eğitim Fakültesi, Matematik ve Fen Bilimleri Eğitimi Bölümü, Fen Bilgisi Eğitimi Anabilim Dal1, e-posta: nisa.yenikalayci@omu.edu.tr, ORCID: 0000-0002-5676-1488
} 


\section{Method}

One sample post-test design was used in the study. The study was conducted with the participation of 60 (54 female and 6 male) first-year students attending the Science Education Department of a Faculty of Education during 2017-2018 spring term. Achievement test and 2 open-ended questions added to achievement test that was prepared by the researchers, were used as data collection tool. 10 units of 4-band resistance were presented in achievement test and students were asked to write the values of the resistances. In analysis of the data obtained from the test, which was carried out in 7 categories: "bands 1 and 2:

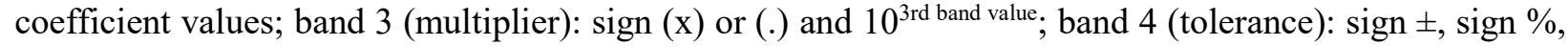
numerical value for gold or silver and the unit". They were asked to write advantages and disadvantages of using simulation through 2 open-ended questions in achievement test. Data obtained were analyzed by content analysis.

\section{Results and Discussion}

It was calculated that the lowest score is 42.9 and the highest point is $\mathrm{X}=100$ by achievement test and mean of the group attended the study is $\overline{\mathrm{X}}=84$.2. It was determined that most of the students gave correct answers in 7 categories. In addition, percentage of students who answered correctly compared to other categories were lower in the unit and sign \pm categories. $25-26 \%$ of the students didn't write sign \pm and 20 $23,3 \%$ of them didn't write the unit.

Students concentrated on mental effects such as memorability, understanding, better comprehending, being challenging and picturing concerning advantages of using simulation. They emphasized that simulation allows meeting the deficiencies and reinforcing through practicing, obtaining meaningful and correct results, doing more exercises, reducing margin of error, practicing outside the laboratory and application independent of reinforcing and concrete material. Students who considered design features of simulation stated that it is advantageous that simulation represents resistance values with colors and engage with visual memory, visual intelligence and the eye. Some of the students state that using simulation enables easy, meaningful and permanent learning, that personal improvement will take place as a result of learning, that simulation helps learning and that learning takes place by observation and they point out positive effects of the application on learning.

While all the students stated that using simulation is advantageous, 24 of these students stated that it has both advantages and disadvantages. Although a simulation that is comprehensible, wieldy, accessible easily by anybody and by which 4-band resistance is displayed visually on the screen was used in the application, it is remarkable that some students indicated disadvantages which are simulation is confusing, individual can't connect with concrete material, usage is not appropriate, it is challenging and everybody can't access to it easily. Besides, it was thought-provoking that a student considered it as a disadvantage that it gave an immediate feedback and a student stated simulation that allowed doing a large number of exercises wasn't sufficient to make practices in spite of the fact that 3 students consider it as a disadvantage that it took long time.

It was determined as a result of the study that using simulation on the teaching of resistance reading with color codes was effective on learning. It was determined that students' opinions on using simulation were positive in general. It was determined that students' opinions on advantages of using simulation centered on codes of "memorable, practical, visual, enjoyable, easy and meaningful learning, time saving, practical usage, making resistance reading easier" and that students' opinions on disadvantages of using simulation mainly focused on codes of "being confusing, desire to see the real one, requiring memorization, being challenging and taking long time".

\section{Suggestions}

It is considered that it is required to use simulations in teaching with regards to ensure a better learning on the subject by making a large number of exercises with low costs and in shorter time.

By the simulation used in this study, students selected colors of the bands on the body of resistance and they saw the value to be taken by the resistance on the display. By another simulation to be prepared as an alternative, student could find a chance to examine colors of the bands on the body of resistance by determining numerical values. In addition, this study may be supported by having students read the resistance values using multimeter simultaneously.

After teaching 4-band resistance reading, a different practice may be carried out in order to show how to conduct 5-band resistance reading process.

In order to encourage students to learn, in the context of showing usage areas of 4-band resistances, it may be possible to allow students to see color-band resistances included in internal structures of the 
instruments by having them examined internal structures of the broken electrically driven or electronic instruments which they use in daily life.

When value of color-band resistances connected to the circuit, varied by its effect on the other circuit components (for example, led) may be tested within the scope of applications to be carried out with Arduino circuits in order to transfer those what are learned. In addition, it is possible to show students that resistances including color bands are used also in robotic applications.

\section{GÍRIŞ}

Fen ve fizik eğitiminin tüm kademelerinde yer alan elektrik ile ilgili ünitelerin temel konularından biri de elektrik devreleridir. En basit hali ile bir elektrik devresi "direnç, anahtar, güç kaynağı..." gibi elemanların bağlantı kablolarıyla birleştirilmesi sonucunda oluşturulur. Öğrenciler aldıkları fen ve fizik eğitimi sürecinde devre elemanlarından biri olan dirençlerle sık sık karşılaşırlar. Karşılaştıkları klasik dirençler ve bunlara ait şekiller nedeniyle direnç denildiğinde zihinlerinde canlanan materyal ve sembolik gösterim benzerlik gösterebilmektedir.

Elektrik-elektronik devrelerinde değişik amaçlar için farklı boyutlara sahip dirençler kullanılabilmektedir (Güneş ve diğerleri, 2017: 117). Elektrikle çalışan aletler ile elektronik aletlerin iç yapılarına öğrencilerin laboratuvar ortamında gördükleri büyük boyutlu dirençlerin sığdırılması mümkün değildir. Bu nedenle bu aletlerin iç yapılarında üzerinde farklı renklerin yer aldığı bantlar taşıyan küçük yapılar -yani renk kodlarına sahip küçük dirençler- yerleştirilerek devre sistemleri kurulmaktadır. Üzerlerindeki bantların sahip olduğu renk değerlerine göre dirençlerin alacağı değerler de değişmektedir.

Dirençlerin değerleri bir ohm $(\Omega)$ 'dan az olabildiği gibi milyonlarca ohm $(\Omega)$ da olabilir. Özdirenci bilinen ve sıkıştırılmış karbondan üretilen karbon dirençler, en sık rastlanan direnç türüdür (Stockley, Oxlade \& Wertheim, 2016). Elektronik devrelerde kullanılan ve farklı bir fiziksel yapıya sahip olan karbon karışımlı dirençler toz halindeki karbonun, reçine tozu ile karışımından yapılır. Karışımın oranı, direncin değerinin büyüklüğünü belirler. Karbon dirençlerin değerlerinin ve bazı özelliklerinin belirlenmesi için üzerlerindeki renk kodları kullanılır (Güneş ve diğerleri, 2017: 118). Direncin değeri belirlenirken önce 1. halkadaki renge karşı1lı gelen sayı, daha sonra onun yanına 2. halkadaki renge karşılık gelen sayı yazılır. İkisinin yanına da 3. halkadaki renge karş1lık gelen adette sıfir eklenir ve ohm $(\Omega)$ cinsinden direncin değeri bulunur. 4. halkadaki renk de bu direncin $\pm \%$ toleransını ifade eder (Millî Eğitim Bakanlığı (MEB), 2012). Bu değerleri okuyarak direncin değerini ifade edebilmenin en kolay yolu öğrencinin her bant için istediği rengi seçerek çok sayıda örnek yapmasına imkân tanıyacak nitelikte uygulamaların kullanılmasıdır. Bu uygulamalar simülasyonlar olarak karşımıza çıkmaktadır.

Simülasyon bir konu, sistem veya olayın modelinin bilgisayarda gerçekleştirilmesidir. Öğrenci modele ait bazı değişkenleri değiştirerek bu değerlerle modelin çalışmasını inceleyebilir (Altın, 2009, s.18). Simülasyon türü bilgisayar destekli öğretim uygulamalarında bilgisayarlar öğrenci girdilerini işleyecek ve anlamlı çıktı verecek şekilde programlanmaktadır (Uşun, 2013: 60). Görsel ve manipülatif ortamlardan biri olan simülasyonlarda program birimlerini seçmeye olanak tanımak ve programı manipülasyona izin vermek için menüler ve butonlar sıkça kullanılmaktadır. Menü ve seçenek sayısının optimum düzeyde tutulması öğrencinin elindeki kontrolü daha etkili ve sistematik olarak kullanmasına izin verir. Bununla birlikte öğrencinin seçimlerine yönelik hareketleriyle ilgili program dönütleri de öğrencinin kendi hareketinin sonucunu takip etmesine yardımc1 olur (Akpınar, 2005: 74). Simülasyonlar, bireyin kendisine sunulan parametreleri değiştirebilmesine olanak sağlaması nedeniyle animasyon veya diğer çoklu ortam uygulamalarından ayrılmaktadır (Ceylan \& Saygıner, 2017). Simülasyonlar, durumların hareketli görüntülerini ve seslerini etkileşimli (interaktif) bir biçimde gösterdiği için vazgeçilmez bir öğretim aracıdır. Simülasyonlar sayesinde fizik eğitiminde laboratuvar yöntemiyle iyi anlatılamayan ve görülemeyen olaylar görülür ve anlaş1lır hale getirilebilir (Bozkurt \& Sarıkoç, 2008).

Araştırma, sorgulama ve üretim bağlamında yetkin bireyler yetiştirmek için teknolojinin sunduğu imkânlardan yararlanılmalıdır (Atam \& Tekdal, 2010). Bu bağlamda son yıllarda fen ve matematik öğretiminde etkili ortamların hazırlanmasında bilgi ve iletişim teknolojileri ile bilgisayar destekli etkileşimli uygulamalardan yoğun şekilde faydalanılmaktadır. Özellikle bilgisayar ve internete erişimdeki hızlı artış nedeniyle bilgiye ulaşma zaman ve mekandan bağımsız hale gelmiş ve eğitim görsel ögelerle desteklenebilir bir nitelik kazanmıştır (Ceylan \& Saygıner, 2017).

Simülasyon programları paradan ve zamandan tasarruf sağlar, riski azaltır ve karar verme durumlarında çok etkilidir. Bunlara ek olarak çok iyi tasarlanmış bir simülasyon programı ile sınıf içi bilgileri yaşamdakine benzer bir ortama taşıyarak daha etkili bir öğrenme sağlanabilir (Demirci, 2003: 45). Her seviyeden ve her yaştan öğrenciye uygulanabilecek simülasyonlarda bir durum, muhtemel tehlikelerin 
kontrol edildiği bir ortamda yeniden canlandırılmaktadır (Aytaş \& Uysal, 2017). Simülasyonlarda yaşamda karşılaşılması muhtemel durumlar ve uygulanabilecek deneyimler tehlike ve olumsuzluklar giderilerek sınıf ortamında sunulur (Engin, Tösten \& Kaya, 2010). Tehlikeli deneylerde güvenliği, olayın gerçekleşme zamanının hızlandırılıp yavaşlatılmasını, çok nadir görülen olayların incelenmesini, karmaşık sistemlerin basitleştirilmesini sağlayan simülasyonlar; kullanışlı, ekonomik ve tekrar edilebilirlik özellikleri ile oldukça avantajlı öğretim araçlarıdır (Tekdal, 2002). Yaşamda karşılaşabileceğimiz durumları yaşamadan yapabilme ve riske girmeden bu durumların sonuçlarını görebilme simülasyonlar ile mümkündür. $\mathrm{Bu}$ sayede öğrenciler çok tehlikeli bir deneyi ve deneyin sonuçlarını bilgisayar ortamında yapıp izleyebilirler. Ayrıca, çok pahalı madde veya araç-gereçler olmadan, uzun süre beklemeden deneyin etkilerini ve sonuçlarını görebilir; bu işlemi istedikleri kadar tekrarlayabilirler.

Simülasyonlar, öğrenenin bir durumu etkileyen unsurları görerek karar vermesini, yanlışları düzeltmesini ve sonuçları anlamlandırmasını sağlamak amacıyla kullanılırlar (Engin ve diğerleri, 2010). Simülasyonlar, kullanıcıların görülemeyecek olan süreçlerin temsillerini gözlemlemesine ve etkileşime girmesine izin verirler (Honey \& Hilton, 2011). Öğrenen birey, simülasyonlarda parametreleri değiştirebilir ve durumu kontrol edebilir. Böylece öğrenme sürecinde simülasyon ile etkileşime girer (Tekdal, 2002).

Simülasyon gibi etkileşime dayalı materyaller öğreneni konunun içine çekerek eğitimi daha verimli hale getirirler (Kör, Çataloğlu \& Erbay, 2013). Öğretimi cazip ve verimli hale getirmek için kullanılabilecek (Akçay ve Şişe, 2014) simülasyonlar bireylerin öğrenmeye yönelik olumlu tepki göstermeleri ve konuyu daha iyi öğrenmeleri üzerinde etkilidir (Aslan-Efe, Oral, Efe \& Öner-Sünkür, 2011). Simülasyonlar öğrenenin kendi sorularını araştırmasına, kendi bilgilerini inşa etmesine ve kendi öğrenmelerini kontrol etmesine imkân sunarlar (Pekdağ, 2010). Simülasyonlar, öğrenenin temel fikir ve kavramları zihninde yapılandırmasını destekleyerek nitelikli bir öğrenme sağlamaktadır (Yılmaz \& Eren, 2014). Anlaşılması zor konuların daha kolay anlaşılmasını, kavramların somutlaştırılmasını, kavram yanılgılarının azalmasını ve kalıcı öğrenmeyi sağlayan (İlyasoğlu \& Aydın, 2014) simülasyonlar yaratıcılığı geliştirmede de etkilidir (Katırc1 \& Satıc1, 2010).

Alanyazın incelendiğinde ilkokul 4. sınıf öğrencilerine dengeli beslenme (Keçeci, Yıldız \& KırbağZengin, 2016), ortaokul 5. sınıf öğrencilerine elektrik (Şimşek, 2017), 6. sınıf öğrencilerine bileşke kuvvet (Dağdalan \& Taş, 2017), ortaokul 7. sınıf öğrencilerine kurbağanın diseksiyonu, anatomisi ve morfolojisi (Akpan \& Andre, 1999), lise 9. sınıf öğrencilerine optik (Emrahoğlu \& Bülbül, 2010), fizik (Korkmaz \& Yıldız, 2012), elektrik devreleri (Ronen \& Eliahu, 2000), hız ve ivme (Jimoyiannis \& Komis, 2001), lise 10. sınıf öğrencilerine mikrobiyoloji (Huppert, Lomask \& Lazarowitz, 2002) ve fotosentez (Aslan-Efe ve diğerleri, 2011), lise 11. sınıf öğrencilerine elektrik akımı (Bakaç, Kartal-Taşoğlu \& Akbay, 2011), yeryüzünde hareket (Coşkun \& Özdemir, 2013), lise öğrencilerine fizik (Kert \& Tekdal, 2008), fen bilgisi 1. sınıf öğretmen adaylarına doğru akım devreleri (İlyasoğlu \& Aydın, 2014), fen bilgisi 2. sınıf öğretmen adaylarına sinir sistemi (Keçeci, Kırbağ-Zengin \& Alan, 2016a) ve kas sistemi (Keçeci, Kırbağ-Zengin \& Alan, 2016b), sınıf öğretmenliği 2. sinıf öğrencilerine yeryüzünde hareket (Aycan, Ar1, Türkoğuz, Sezer \& Kaynar, 2002) ve basit elektrik devreleri (Y1lmaz \& Eren, 2014), eğitim fakültesi fizik eğitimi ve fen edebiyat fakültesi fizik bölümü öğrencilerine alternatif akım devreleri (Bozkurt \& Sarıkoç, 2008), lisans öğrencilerine elektronik (Baltzis \& Koukias, 2009), biyoloji ve kimya eğitimi öğrencilerine geometrik optik (Bayrak, 2008) konularının öğretiminde, fizik eğitimi öğrencilerine elektronik laboratuvarında diyot deneylerinde (Tanel \& Önder, 2010), bilgisayar ve öğretim teknolojileri öğretmenliği 2. sınıf ve lise 2. sinıf öğrencilerine iletken telin direncinin kesit ve uzunluğa bağlı değişimi konulu deneyde (Özdener, 2005) simülasyon kullanımının akademik başarı üzerinde pozitif etkilerinin olduğu görülmektedir.

Simülasyon içeren web tabanlı öğrenme ortamını kullanan ortaokul 8. sınıf öğrencilerinin sözel problemlerin anlamlandırılması ve çözümünde daha başarılı oldukları saptanmıştır (Karal, Çebi, Pekşen \& Turgut, 2010). Simülasyon ile gerçekleştirilen deneylerin lise 10. sınıf öğrencilerinin yer değiştirme ve hız kavramlarını anlama ve algılamaları üzerinde etkili olduğu belirlenmiştir (Şengel, Özden \& Geban, 2002). Elektromanyetizma konularının öğretiminde kullanılan bilgisayar simülasyon oyunlarının 8. sınıf öğrencilerinin karmaşık fizik olgularını anlamalarında yardımcı olduğu saptanmıştır (Squire, Barnett, Grant \& Higginbotham, 2004). Simülasyon kullanımının 7. sınıf öğrencilerinin kinetik moleküler teoriyi anlamaları üzerinde etkili olduğu tespit edilmiştir (Stern, Barnea \& Shauli, 2008). Elektronik ile ilgili konuların öğretiminde kullanılan devre simülasyonlarının lisans öğrencilerinin kavramlara odaklanmalarını sağlamada etkili olduğu anlaşılmıştır (Baltzis \& Koukias, 2009). Simülasyonların elektrik devrelerini (Zacharia, 2007) ve gaz yasalarını (Abdullah \& Shariff, 2008) kavramsal anlama ve bilimsel düşünme üzerinde etkili olduğu saptanmıştır (Abdullah \& Shariff, 2008). Bu sonuçları destekler nitelikte, mühendislik fakültesinde öğrenim gören öğrenciler de akışkanlar mekaniği dersindeki kavramların 
öğretiminde kullanılan simülasyonların kavramları anlamalarına ve revize etmelerine yardımcı olduğunu ifade etmişlerdir (Romero \& Martínez, 2012).

İlkokul 4. sınıfta dengeli beslenme (Keçeci ve diğerleri, 2016), 7. sınıfta kütle ve ağırlık (Sarabando, Cravino \& Soares, 2014), sınıf öğretmenliği program1 2. sınıfta basit elektrik devreleri (Y1lmaz \& Eren, 2014), hücre teorisi (Kiboss, Ndirangu \& Wekesa, 2004) ve fizik (Chang, Chen, Lin \& Sung, 2008) konularının öğretiminde simülasyon kullanımının öğrenme üzerinde etkili olduğu saptanmıştır.

Ortaokul 5. sınıf elektrik (Şimşek, 2017), ortaöğretim 9. sınıf optik (Emrahoğlu ve Bülbül, 2010) üniteleri ile lise fizik öğretiminde (Kert \& Tekdal, 2008) simülasyon kullanılarak gerçekleştirilen öğretimin öğrencilerin edindikleri bilgilerin kalıcılık düzeyini arttırdığı belirlenmiştir. Ayrıca ortaokul 5. sınıf öğrencilerinin sera etkisi ile ilgili oluşturdukları temsillerde kullandıkları kavramların simülasyon kullanımı neticesinde zenginleștiği saptanmıştır (Kukkonen, Kärkkäinen, Dillon \& Keinonen, 2014).

Nehirdeki yaşam konusunda kullanılan simülasyonun fen bilgisi eğitimi öğrencilerinin kavramsal anlamaları üzerinde etkili olduğu belirlenmiştir (Kumar \& Sherwood, 2007). Kavram karikatürleriyle zenginleştirilmiş çalışma yaprakları ve simülasyon programı kullanılarak gerçekleştirilen kavramsal değişim temelli öğretimin fen bilgisi 1. sınıf öğretmen adaylarının doğru akım devreleri konusundaki kavramsal anlamalarını arttırdığı ve kavram yanılgılarını azalttığı ortaya koyulmuştur (Taşlıdere, 2014).

Simülasyon kullanılarak gerçekleştirilen öğretiminin lise 10. sınıf öğrencilerinin fizik (YolaşKolçak, Moğol \& Ünsal, 2014), lisans öğrencilerinin difüzyon ve osmoz (Meir, Perry, Stal, Maruca \& Klopfer, 2005) konularındaki kavram yanılgılarının giderilmesi üzerinde etkili olduğu saptanmıştır. Lise 9. sınıfta elektrik devrelerinin öğretiminde simülasyonun yapıcı bir geribildirim kaynağı olduğu, kavram yanılgılarının belirlenmesi ve düzeltilmesinde etkili olduğu belirtilmiştir (Ronen \& Eliahu, 2000). Suyun molekül yapısının öğretiminde simülasyon kullanımının lise öğrencilerin suyun moleküler yapısı hakkındaki mevcut düşüncelerinde değişime neden olduğu belirlenmiştir (Hakerem, Dobrynina \& Shore, 1993).

Laboratuvar etkinlikleri ile birlikte kullanılan simülasyonların ilkokul 4 ve 5. sinıf öğrencilerinin elektrik (Jaakkola \& Nurmi, 2008), 5 ve 6. sinıf öğrencilerinin elektrik devreleri (Jaakkola, Nurmi \& Veermans, 2011) konularını anlamaları; 6 ve 7. sınıf öğrencilerinin fen başarıları (Shaw \& Okey, 1985) ve sınıf öğretmenliği programı 2. sınıf öğrencilerinin basit elektrik devreleri ve devre elemanlarının kullanımı konusunda deneysel süreç becerileri (Ulukök, Çelik \& Sarı, 2013) üzerinde olumlu etkileri olduğu saptanmıştır.

6. sınıf öğrencileri bileşke kuvvet (Dağdalan \& Taş, 2017), lise 11. sınıf öğrencileri solunum zinciri (Yaman, 2005), lise öğrencileri karmaşık ve dinamik biyoloji (Yaman \& Nerdel, 2008) konularının öğretiminde simülasyon kullanımının derse yönelik ilgilerini arttırdığını ifade etmişlerdir. Başka bir çalışmada da alternatif akım devreleri konularının öğretiminde simülasyon kullanımının fizik eğitimi ve fizik bölümü öğrencilerinin derse yönelik ilgilerini arttırdığı gözlemlenmiştir (Bozkurt \& Sarıkoç, 2008).

Lise 11. sınıf öğrencileri solunum zinciri konusunun öğretiminde kullanılan simülasyonun bilgi kazanma ve kullanma üzerinde pozitif etkileri olduğunu (Yaman, 2005), lise öğrencileri karmaşık ve dinamik bir biyoloji konusunun bilgisayar simülasyonu ile öğretilmesinin bilgilerinde olumlu değişiklikler yaptığını (Yaman \& Nerdel, 2008) belirtmişlerdir. Eğitim fakültesi fizik eğitimi ve fen edebiyat fakültesi fizik programlarında alternatif akım devreleri konularının öğretiminde simülasyon kullanımının öğrencilerin kendi kendilerine öğrenmeleri üzerinde büyük etkisinin olduğu gözlemlenmiştir (Bozkurt \& Sarıkoç, 2008).

Yüksek lisans yapmış fen öğretmenlerinin mekanik, dalga / optik ve termal fizikteki olgularla ilgili yaptıkları açıklamaların niteliği ve kalitesi üzerinde bilgisayar simülasyonlarının olumlu bir etki oluşturduğu saptanmıştır (Zacharia, 2005). Okul öncesi öğretmen adaylarına ayın evrelerinin öğretiminde kullanılan simülasyonun bilimsel anlayışın geliştirilmesinde (Bell \& Trundle, 2008), fizik konularında ise soyut düşünme becerileri (Chang, Chen, Lin \& Sung, 2008) üzerinde etkili olduğu belirlenmiştir.

Simülasyon kullanılarak gerçekleştirilen öğretimin ilkokul 4. sınıf öğrencilerinin fen ve teknoloji dersine (Keçeci ve diğerleri, 2016), 6. sınıf öğrencilerinin bilgisayar destekli fen öğretimine (Dağdalan \& Taş, 2017), ortaokul öğrencilerinin fene (Chen \& Howard, 2010) yönelik tutumları ile ortaokul öğrencilerinin bilim adamlarına yönelik algıları üzerinde olumlu etkileri olduğu saptanmıştır (Chen \& Howard, 2010).

Video ve simülasyonlar soyut kavramları somutlaştıran, öğrenme sürecini görsel unsurlarla zenginleştiren ilgi çekici öğretim araçlarıdır. Öyle ki, ortaokul 5. sınıfta elektrikle ilgili konuların ögretiminde kullanılan animasyon ve simülasyon uygulamasına yönelik öğrencilerin düşüncelerinin genel 
olarak olumlu olduğu, öğrencilerin eğlendikleri ve derse katılım isteklerinin arttığı tespit edilmiştir (Şimşek, 2017).

Ortaokul 6. sınıf öğrencileri kuvvet ve hareket ile 1şık ve ses ünitelerinde kullanılan simülasyonların kavramları somutlaştırarak öğrenmeyi kolaylaştırdığını, öğrenmeye katkı sağladığını, kavramsal öğrenmeyi arttırdığını, simülasyonları verimli ve eğlenceli bulduklarını, evdeki bilgisayarlarında da kullanabildikleri için tekrar imkânı elde ettiklerini, simülasyon yardımı ile yaratıcılıklarını kullanarak farklı süreçleri takip edebildiklerini, hipotez kurma, deney yapma, model oluşturma ve sonuç çıkarma-yordama gibi temel bilimsel süreç becerileri üzerinde simülasyonların olumlu etkileri olduğunu ifade etmişlerdir. Ayrıca öğrenciler imkânsızlıklar nedeniyle yapamadıkları fizik deneylerini simülasyon ortamında değişkenleri değiştirerek yapabildikleri için hipotez kurma ve bu hipotezlere dayanarak sonuç çıkarmayordama gibi önemli bilimsel süreç becerilerini kazandıklarını belirtmişıerdir (Özer, Canbazoğlu-Bilici \& Karahan, 2016).

Ortaokul 8. sınıf öğrencileri simülasyonun uygulama yapmaya, sonuçları kontrol etmeye, soru üretmeye imkân tanıdığını; görsel ve dinamik bir sistem olması nedeniyle dikkat çektiğini ve problem çözerken zevk almayı sağladığını ifade ederek olumlu görüş belirtmişlerdir (Karal ve diğerleri, 2010). Ortaokul 8. sınıf öğrencileri (Karal ve diğerleri, 2010) ile lise 9. sınıf öğrencileri (Ronen \& Eliahu, 2000) simülasyonların özgüvenlerine katkı sağladığını ve motivasyonlarını arttırdığını ifade etmişlerdir.

Lise 9. sınıf öğrencileri elektrik devrelerinin öğretiminde simülasyonu evde öğrenme ortamı olarak kullanmayı diğer ödev aktivitelerinden daha ilginç ve etkili bulduklarını ifade etmişlerdir. Ayrıca öğrenciler öğrenme konusunda daha fazla sorumluluk almalarını sağlayan yapıcı bir geri bildirim kaynağı olan simülasyonun potansiyelini fark etmişlerdir (Ronen \& Eliahu, 1999).

Sınıf öğretmenliği 2. sınıf öğrencileri basit elektrik devreleri ve devre elemanlarının kullanımı konusunun öğretiminde kullanılan simülasyonların tekrar etme imkânı sunduğunu, soyut kavramları somutlaştırdığını, çok boyutlu düşünme imkânı sağladığını, etkili ve kalıcı öğrenmeyi sağladığını, deneyleri eğlenceli hale getirdiğini, güvenli olduğunu, derse karşı ilgilerini arttırdığını, deney araç-gereçlerini tanıma ve farkındalık oluşturma ile korku ve kaygılarını yenmede etkili olduğunu ifade etmişlerdir (Ulukök ve diğerleri, 2013). Benzer şekilde sınıf öğretmenliği 2. sınıf öğrencileri yeryüzünde hareket konusunun simülasyon kullanılarak öğretiminin oldukça ilgi çekici ve akılda kalıcı olduğunu belirtmişlerdir (Aycan ve diğerleri, 2002).

Lisans öğrencileri simülasyonla çalışmayı tercih ettiklerini ve simülasyonun kendilerine proteinlerin yapıları hakkında daha fazla şey öğrettiğini ifade etmişlerdir (White, Kahriman, Luberice \& Idleh, 2010).

Teknik eğitim fakültesi elektronik, elektronik laboratuvarı derslerinde gerçekleştirilen simülasyon uygulamalarından elde edilen sonuçlar gerçek devrelerin test edilebileceğini, yüksek maliyetli deneylerin kolayca yapılabileceğini, her konuda deney düzeneği hazırlanabileceğini, simülasyonların öğrencinin bilgisinin test edilmesinde, problem çözme bilgisinde ve işlemi görüntülemede son derece verimli olduğunu ortaya koymuştur (Akıncı \& Sevindik, 2007).

Simülasyon deneylerinin gerçek araç-gereç kullanılarak yapılan deneyler kadar etkili olduğu saptanmıştır (Tanel \& Önder, 2010). Ulusal alanyazında yer alan çalışmalarda fen bilgisi eğitiminde kullanılan simülasyonların genel olarak etkili olup akademik başarıyı büyük oranda arttırdığı belirtilmiştir (Dinçer \& Güçlü, 2013). Bununla birlikte simülasyonların anlaşılması zor konuların anlaşılmasını kolaylaştırdığı, soyut kavramları somutlaştırdığı, kavram yanılgılarını azaltarak kalıcı öğrenmeyi sağladığ1 ortaya koyulmuştur (İlyasoğlu \& Aydın, 2014).

$\mathrm{Bu}$ araştırma ile alanyazında ortaya koyulan olumlu sonuçlar ışığında elektrik konusunun temel unsurlarından biri olan devreyi oluşturan elemanlardan direnç ile ilgili olarak renk kodları ile direnç okumanın öğretiminde simülasyon kullanımının öğrenme üzerindeki etkisi ve öğrencilerin görüşlerinin incelenmesi amaçlanmıştır.

\section{YÖNTEM}

\subsection{Araştırmanın deseni}

Araştırmada tek örneklem son test desen kullanılmıştır. Bu modele göre rastgele seçilmiş bir tek gruba bağımsız değişken uygulanır ve bağımsız değişkenin bağımlı değişken üzerindeki etkisi incelenir (Karasar, 2004: 96). Uygulama sürecine ilişkin şema Şekil 1'de verilmiştir. 


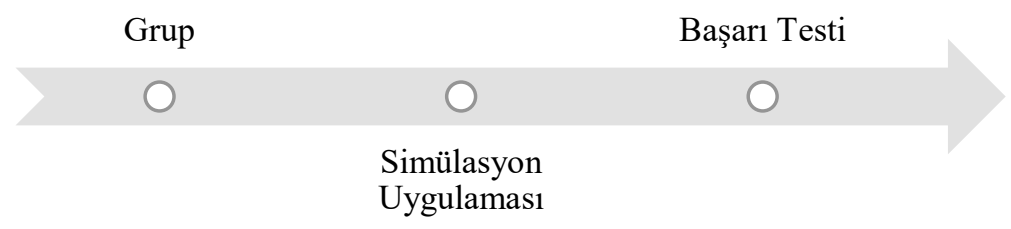

Şekil 1. Uygulama süreci

Bu araştırma kapsamında belirlenen gruba simülasyon kullanılarak renk kodları ile direnç okumanın öğretimine yönelik uygulama yapılmıştır. Uygulama sonunda renk kodları ile direnç okumanın öğretiminde simülasyon kullanımının öğrenme üzerindeki etkisinin belirlenmesi ve öğrencilerin görüşlerini saptamak için gruba simülasyon kullanımının avantaj ve dezavantajlarını ifade etmelerinin istendiği 2 açık uçlu sorunun da yer aldığı bir başarı testi uygulanmıştır.

\subsection{Araştırma grubu}

Araştırma 2017-2018 bahar yarıyılında Fen Bilgisi Eğitimi Anabilim Dalı birinci sınıfta öğrenim gören 54 kız, 6 erkek olmak üzere 60 öğrencinin katılımıyla gerçekleştirilmiştir.

\subsection{Veri toplama araçları}

Veri toplama aracı olarak araştırmacılar tarafından hazırlanan başarı testi kullanılmıştır. Başarı testinde, farklı renk kombinasyonlarının ve direnç değerlerinin eşit dağılımını sağlamak için 10 adet 4 bantlı direnç verilmiş ve öğrencilerden dirençlerin değerlerini yazmaları istenmiştir. Ayrıca başarı testine 2 açık uçlu soru eklenerek ögrencilerden simülasyon kullanımının avantaj ve dezavantajlarını ifade etmeleri istenmiştir.

\subsection{Uygulama süreci}

Araştırma Genel Fizik Laboratuvarı-II dersi kapsamında gerçekleştirilmiştir. Uygulama sürecinde öncelikle öğrencilere dirençte yer alan renklerin kodlarının öğretimi yapılmıştır. Bu doğrultuda "SOKAKTA SAYAMAM GİBİ" ifadesi tahtaya düşey doğrultuda yazılarak yanlarına hangi rengi temsil ettikleri ve bu renklerin bulunduğu bantlarda alacakları değerleri içeren bir tablo (Tablo 1) oluşturulmuştur. (S: Siyah, K: Kahverengi, K: Kırmızı, T: Turuncu, S: Sarı, Y: Yeşil, M: Mavi, M: Mor, G: Gri, B: Beyaz)

Tablo 1. Dirençte bulunan bantlardaki renklere ait değerler

\begin{tabular}{|c|c|c|c|c|}
\hline Renk & $\begin{array}{c}\text { 1. bant } \\
\text { (katsayı değeri) }\end{array}$ & $\begin{array}{c}\text { 2. bant } \\
\text { (katsayı değeri) }\end{array}$ & $\begin{array}{l}\text { 3. bant } \\
\text { (çarpan) }\end{array}$ & $\begin{array}{c}\text { 4. bant } \\
\text { (tolerans) }\end{array}$ \\
\hline Siyah & 0 & 0 & $10^{0}$ & \multirow{10}{*}{$\begin{array}{c}\text { Altın: } \pm \% 5 \\
\text { Gümüş: } \pm \% 10\end{array}$} \\
\hline Kahverengi & 1 & 1 & $10^{1}$ & \\
\hline Kirmız1 & 2 & 2 & $10^{2}$ & \\
\hline Turuncu & 3 & 3 & $10^{3}$ & \\
\hline Sar1 & 4 & 4 & $10^{4}$ & \\
\hline Yeşil & 5 & 5 & $10^{5}$ & \\
\hline Mavi & 6 & 6 & $10^{6}$ & \\
\hline Mor & 7 & 7 & $10^{7}$ & \\
\hline Gri & 8 & 8 & $10^{8}$ & \\
\hline Beyaz & 9 & 9 & $10^{9}$ & \\
\hline
\end{tabular}

Öğretim, Şekil 2'de ekran görüntüsü verilen "Direnç Hesaplama Aracı" adlı hazır simülasyon kullanılarak gerçekleştirilmiştir. Gerçekleştirilen uygulamanın verimli olabilmesi için 60 öğrenci 15'er kişilik 4 gruba ayrılarak tüm gruplarda aynı uygulama yapılmıştır. Rastgele seçilen öğrencilerin sırayla laboratuvar ortamında bulunan bilgisayarın başına gitmeleri ve simülasyonda istedikleri renkleri seçerek kendi dirençlerini oluşturmaları istenmiştir. Bu süreç aynı zamanda sınıftaki diğer öğrencilere projeksiyon aracılığıyla yansıtılmıştır. Bu sayede interaktif bir öğrenme ortamı oluşturularak tüm öğrencilerin simülasyonla etkileşime girerek öğrenmeleri sağlanmıştır. Simülasyonda 4 bantlı direnç üzerindeki her bir 
bant için istedikleri renkleri seçerek direncin aldığı değeri gören öğrenciler çok sayıda örnek yapmışlardır. Uygulama 1 ders saatinde tamamlanmıştır.

\section{Direnç Hesaplama Aracı Resistance calculator}

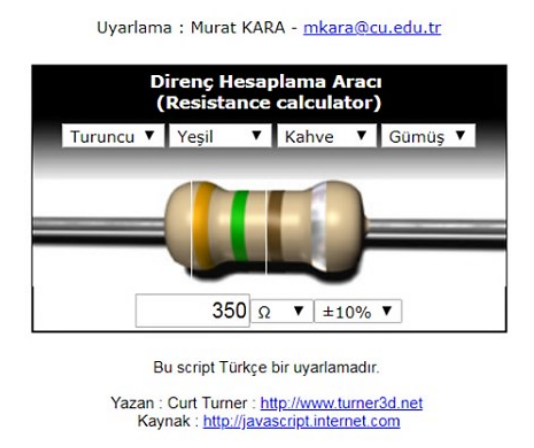

Şekil 2. Direnç hesaplama aracı (URL)

Şekil 2'de görülen simülasyon sayesinde öğrenciler 4 bantlı dirence istedikleri renkleri verebilmekte ve elde ettikleri direncin değerini şeklin alt kısmında yer alan hücrelerde görebilmektedirler. Örnek olarak Şekil 2'de ekran görüntüsü verilen 4 bantlı direnç için hesaplama şu şekilde yapılmaktadır.

- 1. bant "Turuncu" için kat sayı değeri: 3

- 2. bant "Yeşil" için katsayı değeri: 5

- 3. bant "Kahverengi" için çarpan değeri: $10^{1}$

- 4. bant "Gümüş" için tolerans değeri: $\pm \% 10$

Direnç Değeri: $35 \times 10^{1} \pm \% 10 \Omega$

Uygulama sonunda öğrencilere 10 adet 4 bantlı direncin yer aldığ başarı testi ile başarı testine ilave edilen 2 açık uçlu soru uygulanmıştır.

\subsection{Verilerin analizi}

Başarı testinden elde edilen verilerin analizinde "1. ve 2. bant: katsayı değerleri; 3. bant (çarpan): (x)

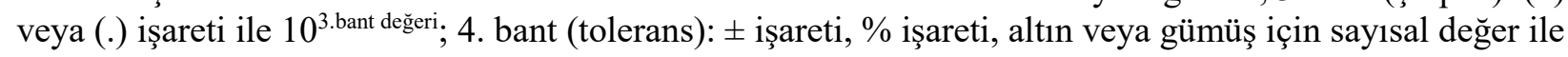
birim" olmak üzere 7 kategoride analiz yapılmıştır. Bu kategorilere uygun olacak şekilde öğrenci cevapları doğru, yanlış ve boş olmak üzere değerlendirilmiş, cevaplara ait yüzde ve frekans değerleri tablolar halinde sunularak yorumlanmıştır. Ayrıca araştırmaya katılan her öğrencinin başarı testinden aldığı puan hesaplanmıştır. Öğrencinin puanı hesaplanırken 7 kategori için her bir kategoriye doğru cevap veren öğrenci 1 puan almıştır. 1 soru için 7 kategoriye de doğru cevap veren öğrenci 7 puan almış, bu değer 10 soru için her soruyu tüm kategorilerde doğru cevaplayan bir öğrenci için 70 puan olmuştur. Başarı testinden alınabilecek en yüksek puan 70 olup bu puan da 100'lük sisteme dönüştürülmüştür. Daha sonra tüm gruba ait aritmetik ortalama hesaplanmıştır.

Başarı testine ilave edilen 2 açık uçlu sorudan elde edilen veriler içerik analizi ile çözümlenmiştir. Veri analizinde "(1) Verilerin kodlanması, (2) Temaların bulunması, (3) Verilerin kodlara ve temalara göre düzenlenmesi ve tanımlanması ve (4) Bulguların yorumlanması" olmak üzere 4 aşama takip edilmiştir (Yıldırım \& Şimşek, 2011). Veri kâğıtlarına her öğrenci için bir numara verilerek öğrenci cevapları olduğu gibi bilgisayara kaydedilmiştir. Ham hali ile okunarak incelenen veriler, güvenirlik açısından bağımsız 2 araştırmacı tarafından kodlanarak kodların yerleştirileceği kategoriler oluşturulmuştur. [Görüş Birliği / (Görüş Ayrılı̆̆ 1 Görüş Birliği) x 100] formülü kullanılarak kodlayıcılar arasındaki güvenirlik hesaplanmıştır (Miles ve Huberman, 1994). İki bağımsız kodlayıcının görüş birliği ve görüş ayrıllı̆ı karşılaştırılarak kodlayıcılar arasındaki güvenirlik \% 96 bulunmuştur. Öğrencilerin cevaplarının birbirleriyle karşılaştırılması sonucunda belirlenen kod ve kategorilere ait frekans değerleri hesaplanmış olup bu değerlere ait tablolar hazırlanarak yorumlanmıştır. Öğrencilerin ifadelerini daha açık ve anlaşılır bir şekilde ortaya koyabilmek için verdikleri cevaplardan doğrudan alıntılar öğrenci numaraları $\left(\ddot{\mathrm{O}}_{1}-\ddot{\mathrm{O}}_{2} \ldots\right)$ ile birlikte sunulmuştur. 


\section{BULGULAR}

Öğrencilerin renk kodları ile direnç okuma konusunda bilgi sahibi olup olmadıklarını anlayabilmek için uygulama öncesinde öğrencilere; "Elinize 4 bantl renkli bir direnç verilse bu direncin değerini nasıl okursunuz? Detaylı bir şekilde açıklayınız.” sorusu yöneltilmiştir. Bu soruya alınan cevaplar neticesinde uygulama öncesinde 4 bantlı renkli bir direncin değerinin nasıl okunacağına 12 öğrenci cevap vermiş, fakat 48 öğrenci cevap verememiş̧tir. Soruya cevap veren 12 öğrenci içerisinde de tam doğru cevap veren öğrencinin olmadığı görülmüştür. Buradan uygulama öncesinde öğrencilerin önemli bir bölümünün 4 bantl1 renkli bir direncin değerinin nasıl okunacă̆ıyla ilgili bilgi sahibi olmadıkları anlaşılmıştır.

Öğrencilere yapılan simülasyon destekli öğretim sonucunda uygulanan başarı testinden elde edilen veriler analiz edilerek $2 \ldots 11$ nolu tablolarda verilmiştir.

Tablo 2. 1. soru (kırmızı-siyah-yeşil-altın) için verilen cevaplara ait frekans (f) ve yüzde (\%) değerleri

\begin{tabular}{|c|c|c|c|c|c|c|c|c|c|c|c|c|c|c|}
\hline & \multirow{2}{*}{\multicolumn{2}{|c|}{$\begin{array}{c}\text { 1. ve } 2 \text {. } \\
\text { bant } \\
\text { (katsay1 } \\
\text { değerleri) }\end{array}$}} & \multicolumn{4}{|c|}{ 3. bant (çarpan) } & \multicolumn{6}{|c|}{ 4. bant (tolerans) } & \multirow{2}{*}{\multicolumn{2}{|c|}{ birim }} \\
\hline & & & \multicolumn{2}{|c|}{$\begin{array}{l}\text { (x) veya }(.) \\
\text { işareti }\end{array}$} & \multicolumn{2}{|c|}{$\begin{array}{l}10^{3 . \text { bant }} \\
\text { değeri }\end{array}$} & \multicolumn{2}{|c|}{ \pm işareti } & \multicolumn{2}{|c|}{$\%$ işareti } & \multicolumn{2}{|c|}{$\begin{array}{l}\text { altın veya } \\
\text { gümüş } \\
\text { için sayısal } \\
\text { değer }\end{array}$} & & \\
\hline & f & $\%$ & f & $\%$ & f & $\%$ & f & $\%$ & f & $\%$ & f & $\%$ & f & $\%$ \\
\hline Doğru & 48 & 80 & 53 & 88,3 & 56 & 93,3 & 43 & 71,7 & 57 & 95 & 54 & 90 & 46 & 76,7 \\
\hline Yanlıs & 12 & 20 & 1 & 1,7 & 4 & 6,7 & 1 & 1,7 & 1 & 1,7 & 6 & 10 & 2 & 3,3 \\
\hline Boş & 0 & 0 & 6 & 10 & 0 & 0 & 16 & 26,7 & 2 & 3,3 & 0 & 0 & 12 & 20 \\
\hline Toplam & 60 & 100 & 60 & 100 & 60 & 100 & 60 & 100 & 60 & 100 & 60 & 100 & 60 & 100 \\
\hline
\end{tabular}

Tablo 2'ye göre, "kırmızı-siyah-yeşil-altın” renk kodlarını içeren 4 bantlı direncin değeri ile ilgili olarak 1. ve 2. bant için katsayı değerlerini öğrencilerin \%80'inin; çarpan olan 3. bant için (x) veya (.)

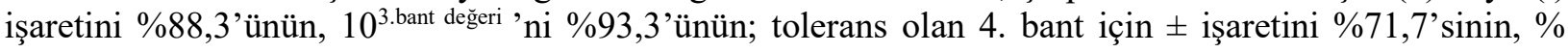
işaretini \%95'inin, altın veya gümüşün temsil ettiği sayısal değeri \%90'ının; birimi \%76,7'sinin doğru yazdığg görülmektedir. (Direnç Değeri: $20 \times 10^{5} \pm \% 5 \Omega$ )

Tablo 3. 2. soru (kahverengi-siyah-mor-gümüş) için verilen cevaplara ait frekans (f) ve yüzde (\%) değerleri

\begin{tabular}{|c|c|c|c|c|c|c|c|c|c|c|c|c|c|c|}
\hline & \multirow{2}{*}{\multicolumn{2}{|c|}{$\begin{array}{l}\text { 1. ve 2. bant } \\
\text { (katsay1 } \\
\text { değerleri) }\end{array}$}} & \multicolumn{4}{|c|}{ 3. bant (çarpan) } & \multicolumn{6}{|c|}{ 4. bant (tolerans) } & \multirow{2}{*}{\multicolumn{2}{|c|}{ birim }} \\
\hline & & & \multicolumn{2}{|c|}{$\begin{array}{l}\text { (x) veya }(.) \\
\text { işareti }\end{array}$} & \multicolumn{2}{|c|}{$\begin{array}{c}10^{3 . \text { bant }} \\
\text { değeri }\end{array}$} & \multicolumn{2}{|c|}{ \pm işareti } & \multicolumn{2}{|c|}{$\%$ işareti } & \multicolumn{2}{|c|}{$\begin{array}{l}\text { altın veya } \\
\text { gümüş } \\
\text { için sayısal } \\
\text { değer }\end{array}$} & & \\
\hline & f & $\%$ & f & $\%$ & $\mathbf{f}$ & $\%$ & f & $\%$ & f & $\%$ & f & $\%$ & f & $\%$ \\
\hline Doğru & 49 & 81,7 & 54 & 90 & 55 & 91,7 & 43 & 71,7 & 57 & 95 & 54 & 90 & 45 & 75 \\
\hline Yanlış & 11 & 18,3 & 2 & 3,3 & 5 & 8,3 & 1 & 1,7 & 0 & 0 & 6 & 10 & 2 & 3,3 \\
\hline Boș & 0 & 0 & 4 & 6,7 & 0 & 0 & 16 & 26,7 & 3 & 5 & 0 & 0 & 13 & 21,7 \\
\hline Toplar & 60 & 100 & 60 & 100 & 60 & 100 & 60 & 100 & 60 & 100 & 60 & 100 & 60 & 100 \\
\hline
\end{tabular}

Tablo 3'e göre, "kahverengi-siyah-mor-gümüş" renk kodlarını içeren 4 bantlı direncin değeri ile ilgili olarak 1. ve 2. bant için katsayı değerlerini ögrencilerin \%81,7'sinin; çarpan olan 3. bant için (x) veya (.) işaretini \%90'ının, $10^{3 \text { bant değeri ' } n i ~ \% 91,7 ' s i n i n ; ~ t o l e r a n s ~ o l a n ~} 4$. bant için \pm işaretini $\% 71,7$ 'sinin, $\%$ işaretini \%95'inin, altın veya gümüşün temsil ettiği sayısal değeri \%90'ının; birimi \%75'inin doğru yazdığ1 görülmektedir. (Direnç Değeri: $10 \times 10^{7} \pm \% 10 \Omega$ ) 
Tablo 4. 3. soru (turuncu-mavi-sar1-gümüş) için verilen cevaplara ait frekans (f) ve yüzde (\%) değerleri

\begin{tabular}{|c|c|c|c|c|c|c|c|c|c|c|c|c|c|c|}
\hline & \multirow{2}{*}{\multicolumn{2}{|c|}{$\begin{array}{c}\text { 1. ve } 2 . \\
\text { bant } \\
\text { (katsay1 } \\
\text { değerleri) }\end{array}$}} & \multicolumn{4}{|c|}{ 3. bant (çarpan) } & \multicolumn{6}{|c|}{ 4. bant (tolerans) } & \multirow{2}{*}{\multicolumn{2}{|c|}{ birim }} \\
\hline & & & \multicolumn{2}{|c|}{$\begin{array}{l}(\mathrm{x}) \text { veya }(.) \\
\text { işareti }\end{array}$} & \multicolumn{2}{|c|}{$\begin{array}{c}10^{3 . b a n t} \\
\text { değeri }\end{array}$} & \multicolumn{2}{|c|}{ \pm işareti } & \multicolumn{2}{|c|}{ \% işareti } & \multicolumn{2}{|c|}{$\begin{array}{l}\text { altın veya } \\
\text { gümüş } \\
\text { için sayısal } \\
\text { değer }\end{array}$} & & \\
\hline & f & $\%$ & $\mathbf{f}$ & $\%$ & $\mathbf{f}$ & $\%$ & $\mathbf{f}$ & $\%$ & $\mathbf{f}$ & $\%$ & $\mathbf{f}$ & $\%$ & $\mathbf{f}$ & $\%$ \\
\hline Doğru & 50 & 83,3 & 53 & 88,3 & 54 & 90 & 44 & 73,3 & 58 & 96,7 & 53 & 88,3 & 45 & 75 \\
\hline Yanlış & 10 & 16,7 & 2 & 3,3 & 6 & 10 & 0 & 0 & 0 & 0 & 7 & 11,7 & 2 & 3,3 \\
\hline Boş & 0 & 0 & 5 & 8,3 & 0 & 0 & 16 & 26,7 & 2 & 3,3 & 0 & 0 & 13 & 21,7 \\
\hline Toplam & 60 & 100 & 60 & 100 & 60 & 100 & 60 & 100 & 60 & 100 & 60 & 100 & 60 & 100 \\
\hline
\end{tabular}

Tablo 4'e göre, "turuncu-mavi-sarı-gümüş" renk kodlarını içeren 4 bantlı direncin değeri ile ilgili olarak 1. ve 2. bant için katsayı değerlerini öğrencilerin \%83,3'ünün; çarpan olan 3. bant için (x) veya (.)

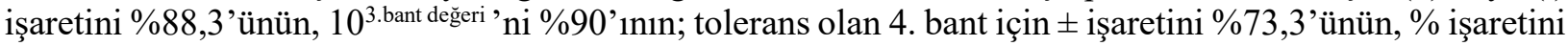
$\% 96,7$ 'sinin, altın veya gümüşün temsil ettiği sayısal değeri \%88,3'ünün; birimi \%75'inin doğru yazdığ görülmektedir. (Direnç Değeri: $36 \times 10^{4} \pm \% 10 \Omega$ )

Tablo 5. 4. soru (mavi-gri-siyah-gümüş) için verilen cevaplara ait frekans (f) ve yüzde (\%) değerleri

\begin{tabular}{|c|c|c|c|c|c|c|c|c|c|c|c|c|c|c|}
\hline & \multirow{2}{*}{\multicolumn{2}{|c|}{$\begin{array}{c}\text { 1. ve } 2 . \\
\text { bant } \\
\text { (katsay1 } \\
\text { değerleri) }\end{array}$}} & \multicolumn{4}{|c|}{ 3. bant (çarpan) } & \multicolumn{6}{|c|}{ 4. bant (tolerans) } & \multirow{2}{*}{\multicolumn{2}{|c|}{ birim }} \\
\hline & & & \multicolumn{2}{|c|}{$\begin{array}{l}\text { (x) veya (.) } \\
\text { işareti }\end{array}$} & \multicolumn{2}{|c|}{$\begin{array}{c}10^{3 . b a n t} \\
\text { değeri }\end{array}$} & \multicolumn{2}{|c|}{ \pm işareti } & \multicolumn{2}{|c|}{$\%$ işareti } & \multicolumn{2}{|c|}{$\begin{array}{l}\text { altın veya } \\
\text { gümüş } \\
\text { için sayısal } \\
\text { değer }\end{array}$} & & \\
\hline & f & $\%$ & $\mathbf{f}$ & $\%$ & $\mathbf{f}$ & $\%$ & f & $\%$ & f & $\%$ & f & $\%$ & $\mathbf{f}$ & $\%$ \\
\hline Doğru & 50 & 83,3 & 48 & 80 & 50 & 83,3 & 43 & 71,7 & 57 & 95 & 53 & 88,3 & 44 & 73,3 \\
\hline Yanlış & 10 & 16,7 & 4 & 6,7 & 7 & 11,7 & 1 & 1,7 & 0 & 0 & 7 & 11,7 & 2 & 3,3 \\
\hline Boș & 0 & 0 & 8 & 13,3 & 3 & 5 & 16 & 26,7 & 3 & 5 & 0 & 0 & 14 & 23,3 \\
\hline Toplam & 60 & 100 & 60 & 100 & 60 & 100 & 60 & 100 & 60 & 100 & 60 & 100 & 60 & 100 \\
\hline
\end{tabular}

Tablo 5'e göre, "mavi-gri-siyah-gümüş" renk kodlarını içeren 4 bantlı direncin değeri ile ilgili olarak 1. ve 2. bant için katsayı değerlerini öğrencilerin \%83,3'ünün; çarpan olan 3. bant için (x) veya (.) işaretini

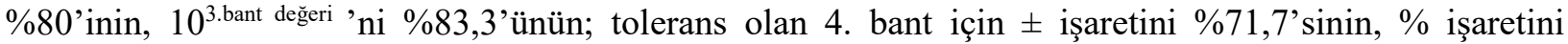
\%95'inin, altın veya gümüşün temsil ettiği sayısal değeri \%88,3’ünün; birimi \%73,3'ünün doğru yazdığ1 görülmektedir. (Direnç Değeri: $68 \times 10^{0} \pm \% 10 \Omega$ )

Tablo 6. 5. soru (kırmızı-siyah-siyah-altın) için verilen cevaplara ait frekans (f) ve yüzde (\%) değerleri

\begin{tabular}{|c|c|c|c|c|c|c|c|c|c|c|c|c|c|c|}
\hline & \multirow{2}{*}{\multicolumn{2}{|c|}{$\begin{array}{c}\text { 1. ve } 2 . \\
\text { bant } \\
\text { (katsay1 } \\
\text { değerleri) }\end{array}$}} & \multicolumn{4}{|c|}{ 3. bant (çarpan) } & \multicolumn{6}{|c|}{ 4. bant (tolerans) } & \multirow{2}{*}{\multicolumn{2}{|c|}{ birim }} \\
\hline & & & \multicolumn{2}{|c|}{$\begin{array}{l}\text { (x) veya (.) } \\
\text { işareti }\end{array}$} & \multicolumn{2}{|c|}{$\begin{array}{c}10^{3 . b a n t} \\
\text { değeri }\end{array}$} & \multicolumn{2}{|c|}{ \pm işareti } & \multicolumn{2}{|c|}{ \% işareti } & \multicolumn{2}{|c|}{$\begin{array}{l}\text { altın veya } \\
\text { gümüş } \\
\text { için sayısal } \\
\text { değer }\end{array}$} & & \\
\hline & f & $\%$ & f & $\%$ & f & $\%$ & $\mathbf{f}$ & $\%$ & f & $\%$ & f & $\%$ & f & $\%$ \\
\hline Doğru & 47 & 78,3 & 50 & 83,3 & 49 & 81,7 & 44 & 73,3 & 58 & 96,7 & 54 & 90 & 44 & 73,3 \\
\hline Yanlış & 13 & 21,7 & 3 & 5 & 6 & 10 & 0 & 0 & 0 & 0 & 6 & 10 & 2 & 3,3 \\
\hline Boș & 0 & 0 & 7 & 11,7 & 5 & 8,3 & 16 & 26,7 & 2 & 3,3 & 0 & 0 & 14 & 23,3 \\
\hline Toplam & 60 & 100 & 60 & 100 & 60 & 100 & 60 & 100 & 60 & 100 & 60 & 100 & 60 & 100 \\
\hline
\end{tabular}

Tablo 6'ya göre, "kırmızı-siyah-siyah-altın" renk kodlarını içeren 4 bantlı direncin değeri ile ilgili olarak 1. ve 2. bant için katsayı değerlerini öğrencilerin \% 78,3'ünün; çarpan olan 3. bant için (x) veya (.)

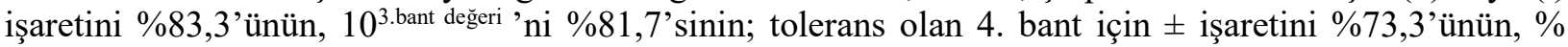
işaretini \%96,7'sinin, altın veya gümüşün temsil ettiği sayısal değeri \%90'ının; birimi \% $\% 3,3$ 'ünün doğru yazdığı görülmektedir. (Direnç Değeri: $20 \times 10^{0} \pm \% 5 \Omega$ ) 
Tablo 7. 6. soru (mavi-turuncu-mavi-altın) için verilen cevaplara ait frekans (f) ve yüzde (\%) değerleri

\begin{tabular}{|c|c|c|c|c|c|c|c|c|c|c|c|c|c|c|}
\hline & \multirow{2}{*}{\multicolumn{2}{|c|}{$\begin{array}{c}\text { 1. ve } 2 . \\
\text { bant } \\
\text { (katsay1 } \\
\text { değerleri) }\end{array}$}} & \multicolumn{4}{|c|}{ 3. bant (çarpan) } & \multicolumn{6}{|c|}{ 4. bant (tolerans) } & \multirow{3}{*}{\multicolumn{2}{|c|}{ birim }} \\
\hline & & & \multicolumn{2}{|c|}{$\begin{array}{l}\text { (x) veya (.) } \\
\text { işareti }\end{array}$} & \multicolumn{2}{|c|}{$\begin{array}{c}10^{3 . \text { bant }} \\
\text { değeri }\end{array}$} & \multicolumn{2}{|c|}{ \pm işareti } & \multicolumn{2}{|c|}{$\%$ işareti } & \multicolumn{2}{|c|}{$\begin{array}{l}\text { altın veya } \\
\text { gümüş } \\
\text { için sayısal } \\
\text { değer }\end{array}$} & & \\
\hline & f & $\%$ & f & $\%$ & f & $\%$ & f & $\%$ & f & $\%$ & f & $\%$ & & \\
\hline Doğru & 47 & 78,3 & 53 & 88,3 & 51 & 85 & 44 & 73,3 & 58 & 96,7 & 54 & 90 & 45 & 75 \\
\hline Yanlıș & 13 & 21,7 & 1 & 1,7 & 9 & 15 & 1 & 1,7 & 0 & 0 & 6 & 10 & 2 & 3,3 \\
\hline Boss & 0 & 0 & 6 & 10 & 0 & 0 & 15 & 25 & 2 & 3,3 & 0 & 0 & 13 & 21,7 \\
\hline Toplam & 60 & 100 & 60 & 100 & 60 & 100 & 60 & 100 & 60 & 100 & 60 & 100 & 60 & 100 \\
\hline
\end{tabular}

Tablo 7'ye göre, "mavi-turuncu-mavi-altın" renk kodlarını içeren 4 bantlı direncin değeri ile ilgili olarak 1. ve 2. bant için katsayı değerlerini öğrencilerin \% 78,3'ünün; çarpan olan 3. bant için (x) veya (.)

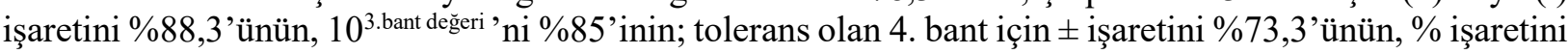
$\% 96,7$ 'sinin, altın veya gümüşün temsil ettiği sayısal değeri \%90'ının; birimi \%75'inin doğru yazdığı görülmektedir. (Direnç Değeri: $63 \times 10^{6} \pm \% 5 \Omega$ )

Tablo 8. 7. soru (kahverengi-kahverengi-kahverengi-gümüş) için verilen cevaplara ait frekans (f) ve yüzde (\%) değerleri

\begin{tabular}{|c|c|c|c|c|c|c|c|c|c|c|c|c|c|c|}
\hline & \multirow{2}{*}{\multicolumn{2}{|c|}{$\begin{array}{c}\text { 1. ve } 2 . \\
\text { bant } \\
\text { (katsay1 } \\
\text { değerleri) }\end{array}$}} & \multicolumn{4}{|c|}{ 3. bant (çarpan) } & \multicolumn{6}{|c|}{ 4. bant (tolerans) } & \multirow{2}{*}{\multicolumn{2}{|c|}{ birim }} \\
\hline & & & \multicolumn{2}{|c|}{$\begin{array}{l}\text { (x) veya }(.) \\
\text { işareti }\end{array}$} & \multicolumn{2}{|c|}{$\begin{array}{c}10^{3 . \text { bant }} \\
\text { değeri }\end{array}$} & \multicolumn{2}{|c|}{ \pm işareti } & \multicolumn{2}{|c|}{$\%$ işareti } & \multicolumn{2}{|c|}{$\begin{array}{l}\text { altın veya } \\
\text { gümüş } \\
\text { için sayısal } \\
\text { değer }\end{array}$} & & \\
\hline & $\mathbf{f}$ & $\%$ & $\mathbf{f}$ & $\%$ & $\mathbf{f}$ & $\%$ & $\mathbf{f}$ & $\%$ & $\mathbf{f}$ & $\%$ & f & $\%$ & $\mathbf{f}$ & $\%$ \\
\hline Doğru & 47 & 78,3 & 53 & 88,3 & 52 & 86,7 & 44 & 73,3 & 56 & 93,3 & 54 & 90 & 46 & 76,7 \\
\hline Yanlış & 13 & 21,7 & 1 & 1,7 & 6 & 10 & 0 & 0 & 0 & 0 & 6 & 10 & 2 & 3,3 \\
\hline Boș & 0 & 0 & 6 & 10 & 2 & 3,3 & 16 & 26,7 & 4 & 6,7 & 0 & 0 & 12 & 20 \\
\hline Topla & 60 & 100 & 60 & 100 & 60 & 100 & 60 & 100 & 60 & 100 & 60 & 100 & 60 & 100 \\
\hline
\end{tabular}

Tablo 8'e göre, "kahverengi-kahverengi-kahverengi-gümüş" renk kodlarını içeren 4 bantlı direncin değeri ile ilgili olarak 1. ve 2. bant için katsayı değerlerini öğrencilerin \%78,3'ünün; çarpan olan 3 . bant

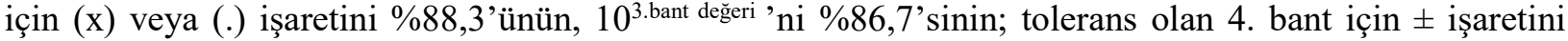
$\% 73,3$ 'ünün, \% işaretini \%93,3'ünün, altın veya gümüşün temsil ettiği sayısal değeri \%90'ının; birimi $\% 76,7^{\prime}$ sinin doğru yazdığı görülmektedir. (Direnç Değeri: $11 \times 10^{1} \pm \% 10 \Omega$ )

Tablo 9. 8. soru (sarı-sar1-turuncu-gümüş) için verilen cevaplara ait frekans (f) ve yüzde (\%) değerleri

\begin{tabular}{|c|c|c|c|c|c|c|c|c|c|c|c|c|c|c|}
\hline & \multirow{2}{*}{\multicolumn{2}{|c|}{$\begin{array}{l}\text { 1. ve 2. bant } \\
\text { (katsay1 } \\
\text { değerleri) }\end{array}$}} & \multicolumn{4}{|c|}{ 3. bant (çarpan) } & \multicolumn{6}{|c|}{ 4. bant (tolerans) } & \multirow{2}{*}{\multicolumn{2}{|c|}{ birim }} \\
\hline & & & \multicolumn{2}{|c|}{$\begin{array}{l}(\mathrm{x}) \text { veya }(.) \\
\text { işareti }\end{array}$} & \multicolumn{2}{|c|}{$\begin{array}{c}10^{3 . \text { bant }} \\
\text { değeri }\end{array}$} & \multicolumn{2}{|c|}{ \pm işareti } & \multicolumn{2}{|c|}{$\%$ işareti } & \multicolumn{2}{|c|}{$\begin{array}{l}\text { altın veya } \\
\text { gümüş } \\
\text { için sayısal } \\
\text { değer }\end{array}$} & & \\
\hline & f & $\%$ & f & $\%$ & $f$ & $\%$ & f & $\%$ & $f$ & $\%$ & f & $\%$ & $\mathbf{f}$ & $\%$ \\
\hline Doğru & 50 & 83,3 & 52 & 86,7 & 53 & 88,3 & 44 & 73,3 & 57 & 95 & 54 & 90 & 45 & 75 \\
\hline Yanlıș & 10 & 16,7 & 1 & 1,7 & 6 & 10 & 0 & 0 & 0 & 0 & 6 & 10 & 3 & 5 \\
\hline Boș & 0 & 0 & 7 & 11,7 & 1 & 1,7 & 16 & 26,7 & 3 & 5 & 0 & 0 & 12 & 20 \\
\hline Toplam & 60 & 100 & 60 & 100 & 60 & 100 & 60 & 100 & 60 & 100 & 60 & 100 & 60 & 100 \\
\hline
\end{tabular}

Tablo 9'a göre, "sarı-sarı-turuncu-gümüş" renk kodlarını içeren 4 bantlı direncin değeri ile ilgili olarak 1. ve 2. bant için katsayı değerlerini öğrencilerin \%83,3'ünün; çarpan olan 3. bant için (x) veya (.)

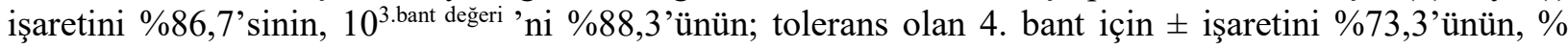
işaretini \%95'inin, altın veya gümüşün temsil ettiği sayısal değeri \%90'ının; birimi \% 75 'inin doğru yazdığı görülmektedir. (Direnç Değeri: $44 \times 10^{3} \pm \% 10 \Omega$ ) 
Tablo 10. 9. soru (mavi-siyah-kırmızı-altın) için verilen cevaplara ait frekans (f) ve yüzde (\%) değerleri

\begin{tabular}{|c|c|c|c|c|c|c|c|c|c|c|c|c|c|c|}
\hline & \multirow{2}{*}{\multicolumn{2}{|c|}{$\begin{array}{c}\text { 1. ve } 2 . \\
\text { bant } \\
\text { (katsay1 } \\
\text { değerleri) }\end{array}$}} & \multicolumn{4}{|c|}{ 3. bant (çarpan) } & \multicolumn{6}{|c|}{ 4. bant (tolerans) } & \multirow{2}{*}{\multicolumn{2}{|c|}{ birim }} \\
\hline & & & \multicolumn{2}{|c|}{$\begin{array}{c}\text { (x) veya }(.) \\
\text { işareti }\end{array}$} & \multicolumn{2}{|c|}{$\begin{array}{c}10^{3 . b a n t} \\
\text { değeri }\end{array}$} & \multicolumn{2}{|c|}{ \pm işareti } & \multicolumn{2}{|c|}{$\%$ işareti } & \multicolumn{2}{|c|}{$\begin{array}{l}\text { altın veya } \\
\text { gümüş } \\
\text { için sayısal } \\
\text { değer }\end{array}$} & & \\
\hline & f & $\%$ & f & $\%$ & f & $\%$ & f & $\%$ & f & $\%$ & $\mathbf{f}$ & $\%$ & f & $\%$ \\
\hline Doğru & 48 & 80 & 55 & 91,7 & 52 & 86,7 & 44 & 73,3 & 58 & 96,7 & 53 & 88,3 & 46 & $\mathbf{7 6 , 7}$ \\
\hline Yanlış & 12 & 20 & 1 & 1,7 & 8 & 13,3 & 0 & 0 & 0 & 0 & 7 & 11,7 & 2 & 3,3 \\
\hline Boş & 0 & 0 & 4 & 6,7 & 0 & 0 & 16 & 26,7 & 2 & 3,3 & 0 & 0 & 12 & 20 \\
\hline Toplam & 60 & 100 & 60 & 100 & 60 & 100 & 60 & 100 & 60 & 100 & 60 & 100 & 60 & 100 \\
\hline
\end{tabular}

Tablo 10'a göre, "mavi-siyah-kırmızı-altın" renk kodlarını içeren 4 bantlı direncin değeri ile ilgili olarak 1. ve 2. bant için katsayı değerlerini öğrencilerin \%80'inin; çarpan olan 3. bant için (x) veya (.)

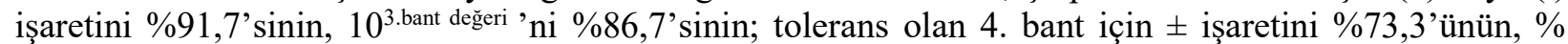
işaretini \%96,7'sinin, altın veya gümüşün temsil ettiği sayısal değeri \%88,3'ünün; birimi \%76,7'sinin doğru yazdığı görülmektedir. (Direnç Değeri: $60 \times 10^{2} \pm \% 5 \Omega$ )

Tablo 11. 10. soru (mor-beyaz-beyaz-altın) için verilen cevaplara ait frekans (f) ve yüzde (\%) değerleri

\begin{tabular}{|c|c|c|c|c|c|c|c|c|c|c|c|c|c|c|}
\hline & \multirow{2}{*}{\multicolumn{2}{|c|}{$\begin{array}{c}\text { 1. ve } 2 \text {. } \\
\text { bant } \\
\text { (katsay1 } \\
\text { değerleri) }\end{array}$}} & \multicolumn{4}{|c|}{ 3. bant (çarpan) } & \multicolumn{6}{|c|}{ 4. bant (tolerans) } & \multirow{2}{*}{\multicolumn{2}{|c|}{ birim }} \\
\hline & & & \multicolumn{2}{|c|}{$\begin{array}{c}(\mathrm{x}) \text { veya }(.) \\
\text { işareti }\end{array}$} & \multicolumn{2}{|c|}{$\begin{array}{c}10^{3 . b a n t} \\
\text { değeri }\end{array}$} & \multicolumn{2}{|c|}{ \pm işareti } & \multicolumn{2}{|c|}{$\%$ işareti } & \multicolumn{2}{|c|}{$\begin{array}{l}\text { altın veya } \\
\text { gümüş } \\
\text { için sayısal } \\
\text { değer }\end{array}$} & & \\
\hline & f & $\%$ & f & $\%$ & $\mathbf{f}$ & $\%$ & f & $\%$ & $\mathbf{f}$ & $\%$ & $\mathbf{f}$ & $\%$ & $\mathbf{f}$ & $\%$ \\
\hline Doğru & 49 & 81,7 & 55 & 91,7 & 56 & 93,3 & 44 & 73,3 & 58 & 96,7 & 53 & 88,3 & 46 & 76,7 \\
\hline Yanlış & 11 & 18,3 & 1 & 1,7 & 4 & 6,7 & 0 & 0 & 0 & 0 & 7 & 11,7 & 2 & 3,3 \\
\hline Boș & 0 & 0 & 4 & 6,7 & 0 & 0 & 16 & 26,7 & 2 & 3,3 & 0 & 0 & 12 & 20 \\
\hline Toplam & 60 & 100 & 60 & 100 & 60 & 100 & 60 & 100 & 60 & 100 & 60 & 100 & 60 & 100 \\
\hline
\end{tabular}

Tablo 11'e göre, "mor-beyaz-beyaz-altın" renk kodlarını içeren 4 bantlı direncin değeri ile ilgili olarak 1. ve 2. bant için katsayı değerlerini öğrencilerin \%81,7'sinin; çarpan olan 3. bant için (x) veya (.)

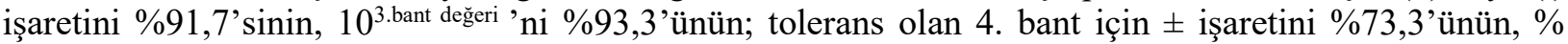
işaretini \%96,7'sinin, altın veya gümüşün temsil ettiği sayısal değeri \%88,3'ünün; birimi \%76,7'sinin doğru yazdığı görülmektedir. (Direnç Değeri: $79 \times 10^{9} \pm \% 5 \Omega$ )

Öğrencilerin başarı testindeki sorulara verdikleri doğru cevapların kategorilere göre frekans (f) ve yüzde (\%) değerleri Tablo 12’de verilmiştir.

Tablo 12. Sorulara verilen doğru cevapların kategorilere göre frekans (f) ve yüzde (\%) değerleri 3. bant (çarpan) 4. bant (tolerans)

1. ve 2. bant

(katsay1 değerleri) (x) veya (.) işareti

\section{$10^{3 . b a n t}$} değeri

\pm işareti $\%$ işareti

altın veya gümüş için sayısal değer

\begin{tabular}{ccccccccccccccc}
\hline Soru & $\mathbf{f}$ & $\mathbf{\%}$ & $\mathbf{f}$ & $\mathbf{\%}$ & $\mathbf{f}$ & $\mathbf{\%}$ & $\mathbf{f}$ & $\mathbf{\%}$ & $\mathbf{f}$ & $\mathbf{\%}$ & $\mathbf{f}$ & $\mathbf{\%}$ & $\mathbf{f}$ & $\mathbf{\%}$ \\
\hline $\mathbf{1}$ & 48 & 80 & 53 & 88,3 & 56 & 93,3 & 43 & 71,7 & 57 & 95 & 54 & 90 & 46 & 76,7 \\
\hline $\mathbf{2}$ & 49 & 81,7 & 54 & 90 & 55 & 91,7 & 43 & 71,7 & 57 & 95 & 54 & 90 & 45 & 75 \\
\hline $\mathbf{3}$ & 50 & 83,3 & 53 & 88,3 & 54 & 90 & 44 & 73,3 & 58 & 96,7 & 53 & 88,3 & 45 & 75 \\
\hline $\mathbf{4}$ & 50 & 83,3 & 48 & 80 & 50 & 83,3 & 43 & 71,7 & 57 & 95 & 53 & 88,3 & 44 & 73,3 \\
\hline $\mathbf{5}$ & 47 & 78,3 & 50 & 83,3 & 49 & 81,7 & 44 & 73,3 & 58 & 96,7 & 54 & 90 & 44 & 73,3 \\
\hline $\mathbf{6}$ & 47 & 78,3 & 53 & 88,3 & 51 & 85 & 44 & 73,3 & 58 & 96,7 & 54 & 90 & 45 & 75 \\
\hline $\mathbf{7}$ & 47 & 78,3 & 53 & 88,3 & 52 & 86,7 & 44 & 73,3 & 56 & 93,3 & 54 & 90 & 46 & 76,7 \\
\hline $\mathbf{8}$ & 50 & 83,3 & 52 & 86,7 & 53 & 88,3 & 44 & 73,3 & 57 & 95 & 54 & 90 & 45 & 75 \\
\hline $\mathbf{9}$ & 48 & 80 & 55 & 91,7 & 52 & 86,7 & 44 & 73,3 & 58 & 96,7 & 53 & 88,3 & 46 & 76,7 \\
\hline $\mathbf{1 0}$ & 49 & 81,7 & 55 & 91,7 & 56 & 93,3 & 44 & 73,3 & 58 & 96,7 & 53 & 88,3 & 46 & 76,7 \\
\hline
\end{tabular}


Tablo 12 incelendiğinde " 1 . ve 2. bant: katsayı değerleri; 3. bant (çarpan): (x) veya (.) işareti ile

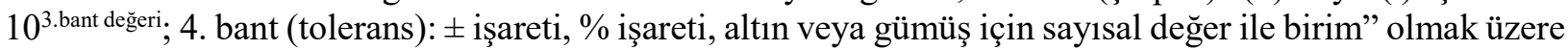
7 kategoride öğrencilerin çoğunluğunun doğru cevap verdiği görülmektedir. Bununla birlikte 7 kategori içerisinde doğru cevap veren öğrenci oranının daha düşük olduğu kategoriler \pm işareti ile birim kategorileridir. Öğrencilerin \%25-\%26,7'lik bölümü \pm işaretini, \%20-\%23,3'lük bölümü birimi yazamamıştır.

Öğrencilerin başarı testinden aldıkları toplam puanlara ait frekans (f) ve yüzde (\%) değerleri Tablo 13 'te verilmiştir.

Tablo 13. Öğrencilerin testten aldıkları toplam puanlara (X) ait frekans (f) ve yüzde (\%) değerleri

\begin{tabular}{cccccccccccc}
\hline $\mathbf{X}$ & $\mathbf{f}$ & $\mathbf{\%}$ & $\mathbf{X}$ & $\mathbf{f}$ & $\mathbf{\%}$ & $\mathbf{X}$ & $\mathbf{f}$ & $\mathbf{\%}$ & $\mathbf{X}$ & $\mathbf{f}$ & $\mathbf{\%}$ \\
\hline $\mathbf{4 2 , 9}$ & $\mathbf{1}$ & $\mathbf{1 , 7}$ & 67,1 & 1 & 1,7 & 84,3 & 2 & 3,3 & 92,9 & 1 & 1,7 \\
\hline 57,1 & 1 & 1,7 & 70 & 7 & 11,7 & 85,7 & 8 & 13,3 & 94,3 & 1 & 1,7 \\
\hline 58,6 & 1 & 1,7 & 71,4 & 7 & 11,7 & 88,6 & 1 & 1,7 & 97,1 & 3 & 5 \\
\hline 62,9 & 1 & 1,7 & 75,7 & 1 & 1,7 & 90 & 1 & 1,7 & 98,6 & 3 & 5 \\
\hline 65,7 & 1 & 1,7 & 81,4 & 3 & 5 & 91,4 & 2 & 3,3 & $\mathbf{1 0 0}$ & $\mathbf{1 4}$ & $\mathbf{2 3 , 3}$ \\
\hline
\end{tabular}

Tablo 13'te 60 öğrencinin başarı testinden aldıkları toplam puanlar görülmektedir. Başarı testinden alınan en düşük puan 42,9 ve en yüksek puan $X=100$ olup, araştırmaya katılan grubun aritmetik ortalaması $\overline{\mathrm{X}}=84,2$ olarak hesaplanmıştır.

Açık uçlu sorulardan elde edilen veriler analiz edilerek Tablo 14 ve 15 'te verilmiştir.

Tablo 14. Öğrencilerin simülasyon kullanımının avantajlarına yönelik görüşleri

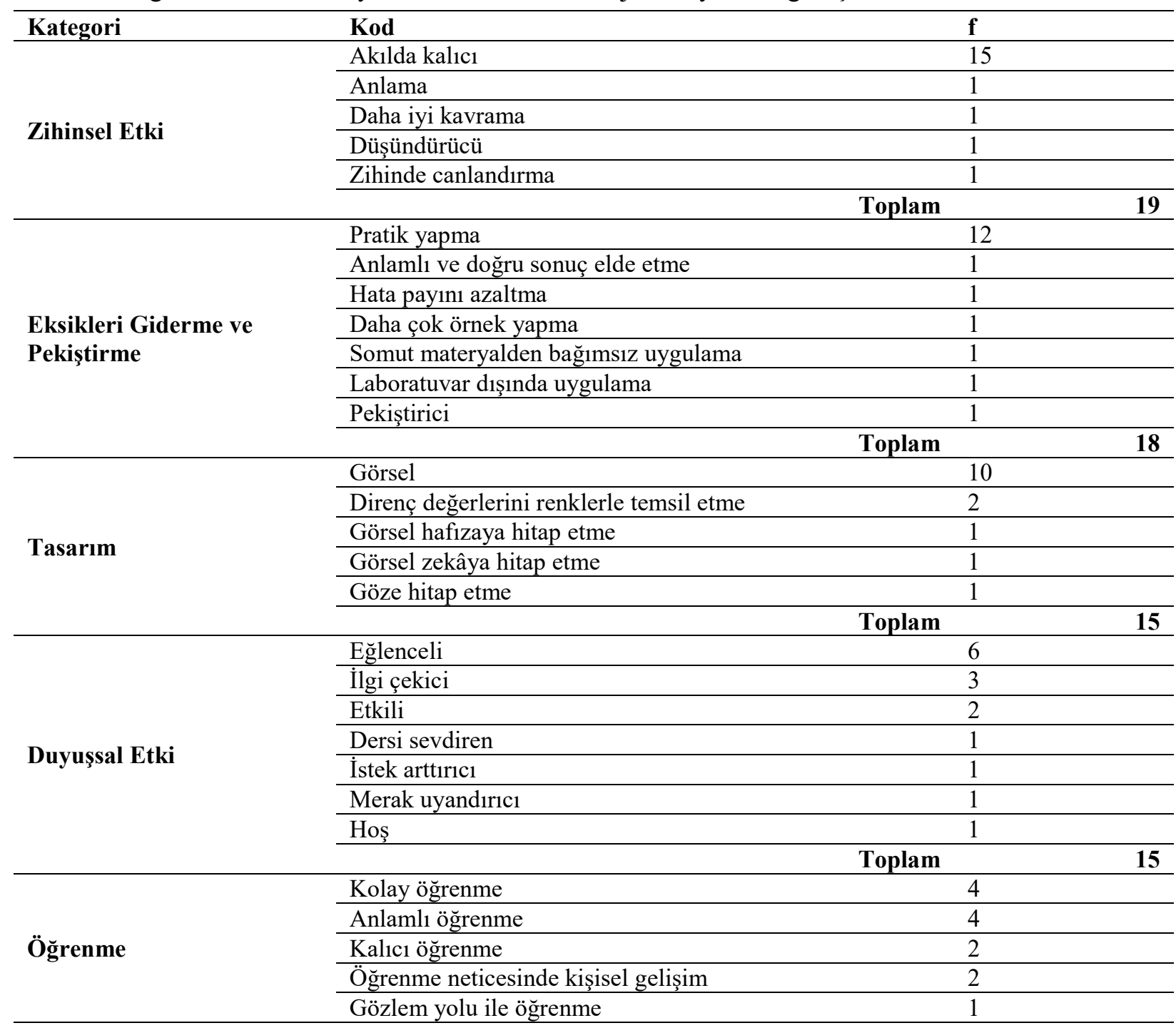




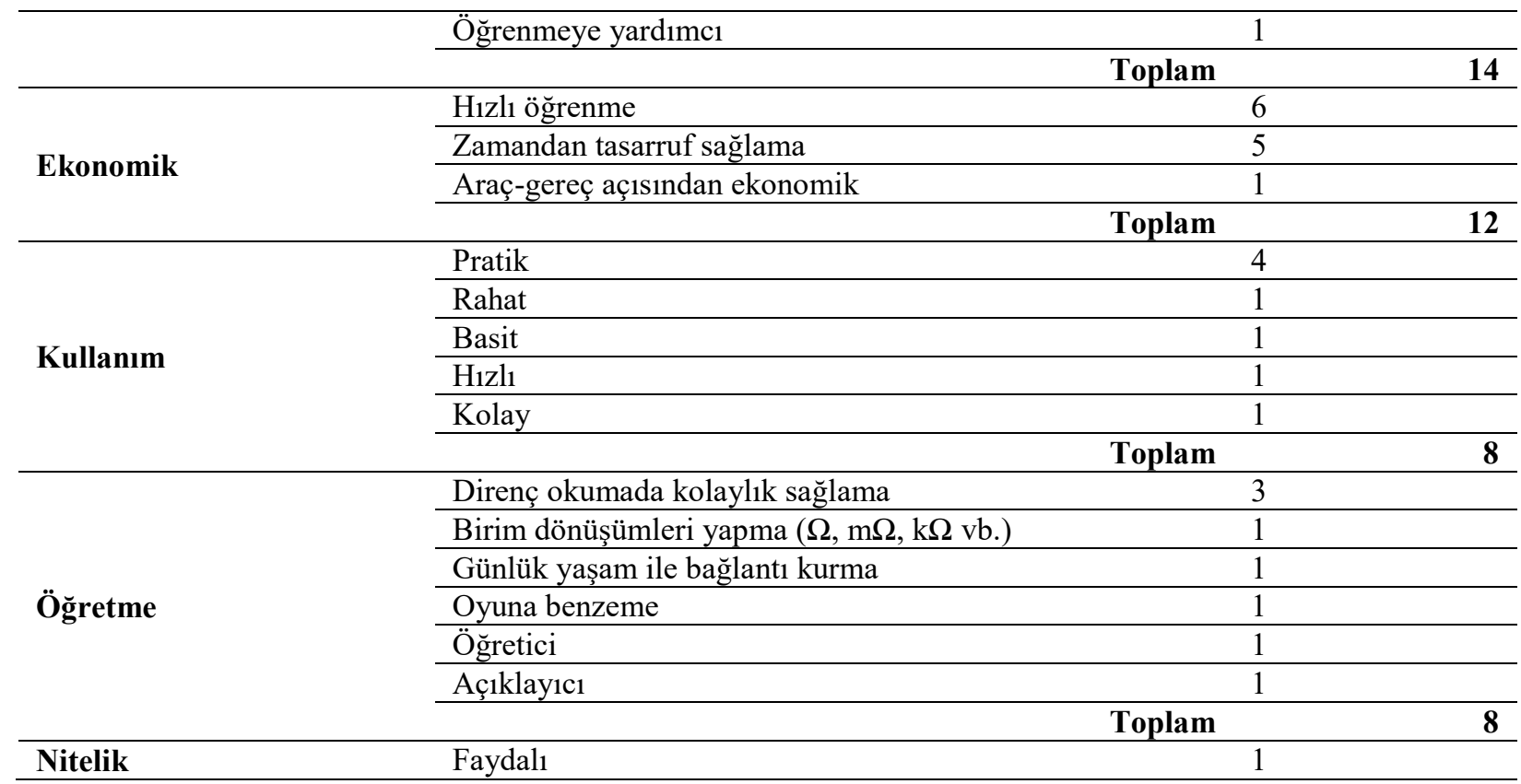

Tablo 14 incelendiğinde öğrencilerin simülasyon kullanımının avantajlarına yönelik görüşlerini zihinsel etki (f:19), eksikleri giderme ve pekiştirme (f:18), tasarım (f:15), duyuşsal etki (f:15), öğrenme (f:14), ekonomik (f:12), kullanım (f:8), öğretme (f:8) ve nitelik (f:1) olmak üzere 9 kategoride ifade ettikleri görülmektedir. Avantajlara yönelik görüşler; akılda kalıcılık, pratik yapma, görsel, eğlenceli, kolay ve anlamlı öğrenme, hızlı öğrenme, zamandan tasarruf sağlama, pratik kullanım, direnç okumada kolaylık sağlama kodlarında yoğunlaşmaktadır. Öğrencilerin görüşlerinden bazı örnekler aşağıda verilmiştir.

zihinsel etki - "Bu konuyu böyle işlediğimiz için benim daha çok aklımda kaldı.” (Ö $\left.{ }_{34}\right)$

eksikleri giderme ve pekiştirme - "Sınıf ortamında bu araç olmasa bile bilgisayar sayesinde ögretilebiliyor ve ögrenilebiliyor." (Ö̈33)

tasarım - "Bazı öğrencilerin hayal etme yetenĕgi zayıf olabileceğinden dolayı görsellik kazandırması büyük bir avantajdır." ("̈̈ $\left.{ }_{22}\right)$

duyuşsal etki - “Öğrenciler renkli şekilde gördüklerinde istekli olacaklarını düşünüyorum.” (Ö̈

ögrenme - "Birçok örnekler yaparak daha iyi öğrenim să̆lar.” (Ö̈26)

ekonomik - "Fazla araç-gereç kullanımı olmuyor.” ( $\left.\ddot{O}_{3}\right)$

kullanım - "Pratik bir yöntem." ( $\left.\ddot{O}_{57}\right)$

ögretme - "Mesela iç yapısını incelediğimiz bozuk araç gereçlerin içindeki küçük dirençlerin büyüklüğünü görmüş olduk.” ( $\left.\ddot{O}_{40}\right)$

nitelik - "Bu tür uygulamalar daha faydalı diye düşünüyorum." $\left(\ddot{O}_{52}\right)$

Tablo 15. Öğrencilerin simülasyon kullanımının dezavantajlarına yönelik görüşleri

\begin{tabular}{|c|c|c|}
\hline Kategori & Kod & f \\
\hline \multirow{4}{*}{ Zihinsel Etki } & Kafa karıştırması & 3 \\
\hline & Renklerin temsil ettiği değerlerin unutulması & 2 \\
\hline & Bireyin somut materyal ile bağlantı kuramaması & 1 \\
\hline & Toplam & 6 \\
\hline \multirow{4}{*}{ Beklenti } & Gerçeğini görme isteği & 3 \\
\hline & Bilgisayara yönelik beklentiyi arttırması & 1 \\
\hline & Hazıra alıştırması & 1 \\
\hline & Toplam & 5 \\
\hline \multirow{4}{*}{ Öğrenme } & Ezber gerektirmesi & 2 \\
\hline & Öğrenmeye katkı sağlamaması & 1 \\
\hline & Sanal öğrenme sağlaması & 1 \\
\hline & Toplam & 4 \\
\hline \multirow{5}{*}{ Tasarım } & Göz ile ilgili hastalıkları olan bireylerin kullanırken zorlanması & 1 \\
\hline & Renklerin ayırt edilememesi & 1 \\
\hline & Kullanım şeklinin uygun olmaması & 1 \\
\hline & Siradan olmas1 & 1 \\
\hline & Toplam & 4 \\
\hline
\end{tabular}




\begin{tabular}{|c|c|c|c|}
\hline \multirow{3}{*}{ Kullanım } & Uğraştırıcı olması & \multirow{2}{*}{\multicolumn{2}{|c|}{$\frac{2}{1}$}} \\
\hline & Amaca uygun kullanılmaması & & \\
\hline & & Toplam & 3 \\
\hline \multirow{4}{*}{$\begin{array}{l}\text { Yeterlilik } \\
\text { (Bireysel, Donanım, } \\
\text { Erişim) }\end{array}$} & Bilgisayar kullanımına yönelik bilginin yetersiz olması & & \\
\hline & Bilgisayar sayısının yeterli olmaması & & \\
\hline & Herkesin ulaşımına açık olmaması & & \\
\hline & & Toplam & 3 \\
\hline Ekonomik & Uzun zaman alması & & \\
\hline \multirow{3}{*}{ Öğretme } & Anında dönüt vermesi & & \\
\hline & Gerekli olmaması & & \\
\hline & & Toplam & 2 \\
\hline $\begin{array}{l}\text { Eksikleri Giderme ve } \\
\text { Pekiştirme }\end{array}$ & Pratik yapma için yeterli olmaması & & \\
\hline Duyuşsal Etki & S1kıc1 olmas1 & & \\
\hline
\end{tabular}

Tablo 15 incelendiğinde öğrencilerin simülasyon kullanımının dezavantajlarına yönelik görüşlerini zihinsel etki (f:6), beklenti (f:5), öğrenme (f:4), tasarım (f:4), kullanım (f:3), yeterlilik (bireysel, donanım, erişim) (f:3), ekonomik (f:3), öğretme (f:2), eksikleri giderme ve pekiştirme (f:1) ve duyuşsal etki (f:1) olmak üzere 10 kategoride ifade ettikleri görülmektedir. Dezavantajlara yönelik görüşler; kafa karıştırması, gerçeğini görme isteği, ezber gerektirmesi, uğraştırıcı olması ve uzun zaman alması kodlarında yoğunlaşmaktadır. Öğrencilerin görüşlerinden bazı örnekler aşağıda verilmiştir.

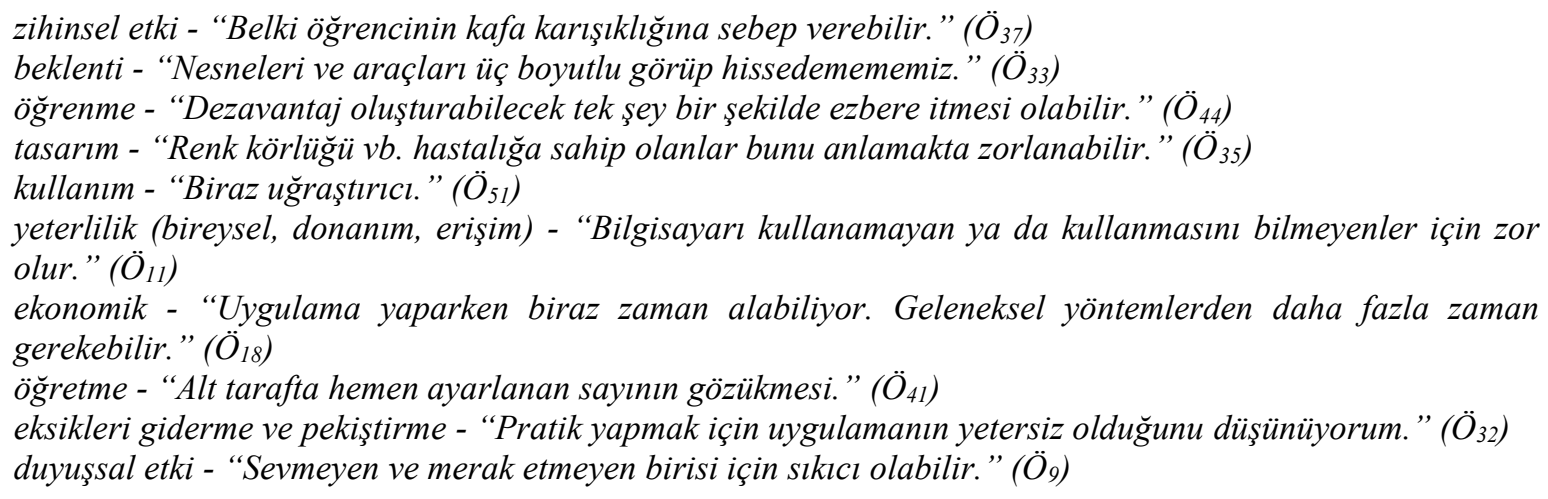

\section{TARTIŞMA ve SONUÇ}

Araştırma sonucunda renk kodları ile direnç okumanın öğretiminde simülasyon kullanımının öğrenme üzerinde etkili olduğu görülmüştür. Alanyazında da simülasyon kullanımının öğrenme üzerinde olumlu etkileri olduğu ortaya koyulmuştur (Chang, Chen, Lin \& Sung, 2008; Keçeci ve diğerleri, 2016; Kiboss, Ndirangu \& Wekesa, 2004; Özer ve diğerleri, 2016; Sarabando, Cravino \& Soares, 2014; Ulukök ve diğerleri, 2013; Y1lmaz \& Eren, 2014).

Fen bilgisi öğrencilerinin renk kodları ile direnç okumanın öğretiminde simülasyon kullanımına yönelik görüşlerinin genel olarak olumlu olduğu saptanmıştır. Alanyazında yer alan çalışmalarda da öğrencilerin simülasyon kullanımına yönelik görüşlerinin olumlu olduğu ortaya koyulmuştur (Aycan ve diğerleri, 2002; Karal ve diğerleri, 2010; Özer ve diğerleri, 2016; Romero \& Martínez, 2012; Ronen \& Eliahu, 1999, 2000; Şimşek, 2017; Ulukök ve diğerleri, 2013).

$\mathrm{Bu}$ araştırmada simülasyon kullanımının avantajlarıyla ilgili olarak fen bilgisi öğrencileri akılda kalıcılık, anlama, daha iyi kavrama, düşündürücü ve zihinde canlandırma olmak üzere zihinsel etkileri üzerinde yoğunlaşmışlardır. Alanyazında da simülasyonların anlama üzerinde etkili olduğu ortaya koyulmuştur (Abdullah \& Shariff, 2008; Jaakkola \& Nurmi, 2008; Jaakkola ve diğerleri, 2011; Squire ve diğerleri, 2004; Stern, Barnea \& Shauli, 2008; Şengel ve diğerleri, 2002; Taşlidere, 2014). Simülasyon kullanımına yönelik ifade edilen görüşlerden de akılda kalıcı oldukları (Aycan ve diğerleri, 2002), kavramları anlama ve revize etmede etkili oldukları (Romero \& Martínez, 2012), çok boyutlu düşünme imkânı sağladıkları (Ulukök ve diğerleri, 2013) anlaşılmaktadır.

Fen bilgisi öğrencileri pratik yapma, anlamlı ve doğru sonuç elde etme, daha çok örnek yapma, hata payını azaltma, laboratuvar dışında uygulama, pekiştirici ve somut materyalden bağımsız uygulama olmak 
üzere simülasyonun eksikleri giderme ve pekiştirme imkânı sunduğunu vurgulamışlardır. Alanyazındaki çalışmalarda da öğrenciler simülasyonları evdeki bilgisayarlarında da kullanabildikleri için tekrar imkânı elde ettiklerini (Ö̈zer ve diğerleri, 2016; Ulukök ve diğerleri, 2013), evde öğrenme ortamı olarak simülasyonları ilginç ve etkili bulduklarını (Ronen \& Eliahu, 1999), simülasyonların uygulama yapmaya, sonuçları kontrol etmeye imkân sağladığını (Karal ve diğerleri, 2010) ifade etmişlerdir.

Simülasyonun tasarım özelliklerini dikkate alan öğrenciler görsel olmasını, direnç değerlerini renklerle temsil etmesini, görsel hafizaya, görsel zekaya ve göze hitap etmesini avantaj olarak ifade etmişlerdir. Alanyazında da öğrenciler simülasyonların görsel ve dinamik sistemler olduğunu (Karal ve diğerleri, 2010) ve öğrenme sürecini görsel unsurlarla zenginleştirdiklerini (Şimşek, 2017) vurgulamışlardır.

Simülasyon kullanımının avantajlarını duyuşsal etki bağlamında ele alan öğrenciler eğlenceli, ilgi çekici, etkili, dersi sevdiren, hoş, istek arttırıcı ve merak uyandırıcı olduğunu ifade etmişlerdir. Benzer şekilde Şimşek (2017) simülasyon kullanılarak gerçekleştirilen öğretim sırasında öğrencilerin eğlendiklerini ve derse katılım isteklerinin arttığını saptamıştır. Özer ve diğerleri (2016) öğrencilerin simülasyonları verimli ve eğlenceli bulduklarını; Ulukök ve diğerleri (2013) öğrencilerin simülasyonların deneyleri eğlenceli hale getirdiğini düşündüklerini saptamışlardır. Bozkurt ve Sarıkoç (2008) simülasyonların derse yönelik ilgiyi arttırdığı gözlemlemiş; Dağdalan ve Taş (2017), Ulukök ve diğerleri (2013), Yaman (2005), Yaman ve Nerdel (2008) öğrencilerin simülasyonun derse yönelik ilgilerini arttırdığını; Aycan ve diğerleri (2002) ise öğrencilerin simülasyonların ilgi çekici olduğunu düşündüklerini ortaya koymuştur. Karal ve diğerleri (2010) öğrencilerin simülasyonun dikkat çekici olduğunu, zevk almay1 sağladığını ve motivasyonlarını arttırdığını düşündüklerini belirlemiştir.

Bazı öğrencilerde simülasyon kullanımının kolay, anlamlı ve kalıcı öğrenmeyi sağladığını, öğrenme neticesinde kişisel gelişimin gerçekleşeceğini, simülasyonun öğrenmeye yardımcı olduğunu ve öğrenmenin gözlem yolu ile sağlandığını ifade ederek uygulamanın öğrenme üzerindeki olumlu etkilerine dikkat çekmişlerdir. Alanyazında yer alan çalışmalarda da simülasyon kullanımının öğrenme üzerinde etkili olduğu ortaya koyulmuştur (Keçeci ve diğerleri, 2016; Y1lmaz \& Eren, 2014). Özer ve diğerleri (2016) öğrencilerin simülasyonların kavramları somutlaştırarak öğrenmeyi kolaylaştırdığını, öğrenmeye katkı sağladığını, kavramsal öğrenmeyi arttırdığını; Ulukök ve diğerleri (2013) ise öğrencilerin simülasyonların etkili ve kalıcı öğrenmeyi sağladığını düşündüklerini tespit etmiştir.

Bazı öğrenciler ise simülasyon kullanımının hızlı öğrenme imkânı sunması, zaman ve araç-gereç bağlamında ekonomik olması nedeniyle avantajlı olduğunu ifade etmiştir. Bir direncin değeri direncin gövdesi üzerine basılmış renkli çizgilerle tanımlanır. Normalde, insanlar bunu görerek de okuyabilirler. Ancak bu işlem bir bilgisayar aracılığı ile gerçekleştirilirse maliyet azaltılabilir (Mallick, Kar, Mohanty \& Kumar, 2015; Mitani \& Hamamoto, 2010). Bu bağlamda simülasyonlar öğrencilere pahalı ekipman eksikliği nedeniyle elde edemeyecekleri deneyimleri yaşama imkânı sundukları için hem maddi hem de zaman açısından son derece ekonomiktirler (Mosterman, Campbell, Brodersen \& Bourne, 1996). Öyle ki, alanyazında da simülasyonlarla yüksek maliyetli deneylerin kolayca yapılabileceği ve her konuda deney düzeneği hazırlanabileceği ifade edilmiştir (Akıncı \& Sevindik, 2007).

Öğrencilerin bir kısmı da pratik, rahat, basit, hızlı ve kolay olan simülasyonun kullanım açısından avantajlı olduğunu belirtmiştir. Bazı öğrenciler ise simülasyon kullanımının direnç okumada kolaylık sağladığını, açıklayıcı olduğunu, birim dönüşümleri yapma imkânı sunduğunu, günlük yaşamla bağlantı kurduğunu, oyuna benzediğini ve öğretici olduğunu ifade ederek uygulamanın öğretme üzerindeki olumlu etkilerine dikkat çekmişlerdir. Bir öğrenci ise simülasyon kullanımının faydalı olmasını avantaj olarak ifade etmiştir.

Tüm öğrenciler simülasyon kullanımının avantajlı olduğunu ifade ederken bu öğrencilerden 24'ü avantajlarının yanında dezavantajlarının da olduğunu belirtmiştir. Uygulamada anlaşılır, kolay kullanılabilen, herkesin kolayca ulaşabileceği ve 4 bantlı direncin görsel olarak ekranda yer aldığı bir simülasyon kullanılmasına karşın bazı öğrencilerin kafa karıştırması, bireyin somut materyalle bağlantı kuramaması, kullanım şeklinin uygun olmaması, uğraştıııcı olması ve herkesin ulaşımına açık olmaması şeklinde ifade ettikleri dezavantajlar dikkat çekicidir. Ayrıca 3 öğrencinin uzun zaman almasını dezavantaj olarak görmelerinin aksine 1 öğrencinin anında dönüt vermesini dezavantaj olarak görmesi ile 1 öğrencinin çok sayıda örnek yapmaya imkân sunan simülasyonun pratik yapma için yeterli olmadığını ifade etmesi düşündürücüdür. Bir öğrencinin ise dezavantaj olarak göz ile ilgili hastalıkları olan bireylerin kullanırken zorlanabileceklerini ifade etmesi renk körü olan öğrencilerin simülasyonu kullanırken bazı sıkıntılar yaşayabileceklerini vurgulaması bağlamında önemlidir. 


\section{ÖNERILLER}

Ucuz maliyetlerle kısa sürede çok sayıda örnek yaparak konunun daha iyi öğrenilmesini sağlama bağlamında simülasyonların öğretimde kullanılmasının gerekli olduğu düşünülmektedir.

$\mathrm{Bu}$ araştırmada kullanılan simülasyon ile öğrenciler, bilgisayar yardımıyla projeksiyondan yansıtılan direncin gövdesindeki bantların renklerini seçerek direncin alacağı değeri ekranda görmüşlerdir. Buna alternatif olarak hazırlanacak olan başka bir simülasyonda da öğrenciler sayısal değerleri belirleyerek direncin gövdesindeki bantların renklerini inceleme imkanı bulabilirler. Ayrıca bu araştırma eş zamanlı olarak multimetre (avometre) kullanılarak öğrencilere direnç değerlerinin okutulmasıyla desteklenebilir.

4 bantlı direnç okumanın öğretiminin ardından 5 bantlı direnç okuma işleminin nasıl yapılacağına yönelik ayrı bir uygulama daha yapılabilir.

Öğrencileri öğrenmeye güdülemek amacıyla renk bantlı dirençlerin kullanım alanlarının gösterilmesi bağlamında öğrencilere günlük yaşamda kullandıkları elektrikli veya elektronik aletlerden bozuk olanların iç yapıları incelettirilerek araçların iç yapılarındaki renk bantlı dirençleri görmeleri sağlanabilir.

Öğrenilenlerin transferini sağlamak için Arduino devreleri ile yapılacak uygulamalar kapsamında devreye bağlayan renk bantlı dirençlerin değeri değiştiğinde diğer devre elemanları üzerindeki etkileri (örneğin; led) test edilebilir. Bunun yanı sıra öğrencilerin robotik uygulamalarda da renk bantları içeren dirençlerin kullanıldığını görmeleri sağlanabilir. 


\section{KAYNAKLAR}

Abdullah, S. \& Shariff, A. (2008). The effects of inquiry-based computer simulation with cooperative learning on scientific thinking and conceptual understanding of gas laws. Eurasia Journal of Mahematics, Science \& Technology Education, 4(4), 387-398.

Akçay, S. \& Şişe, Ö. (2014). Elektron optiğinin öğretilmesinde 1şık optiği ile zenginleştirilmiş analoji kurulumu. Bartın Üniversitesi Ë̆itim Fakültesi Dergisi, 3(2), 273-292.

Akıncı, T.Ç. \& Sevindik, T. (2007). Elektrik ve elektronik eğitiminde tina programının uygulanması. eJournal of New World Sciences Academy, 2(1), 72-77.

Akpan, J.P. \& Andre, T. (1999). The effect of a prior dissection simulation on middle school students' dissection performance and understanding of the anatomy and morphology of the frog. Journal of Science Education and Technology, 8(2), 107-121.

Akpınar, Y. (2005). Bilgisayar destekli eğitimde uygulamalar. (2. Baskı.). Ankara: Anı Yayıncılık.

Altın, K. (2009). Bilgisayar destekli fen ve teknoloji öğretimi - materyal geliştirme ve etkinlik örnekleri. (1. Baskı.). İstanbul: Beta Yayıncılık.

Aslan-Efe, H., Oral, B., Efe, R. \& Öner-Sünkür, M. (2011). The effects of teaching photosynthesis unit with computer simulation supported co-operative learning on retention and student attitude to biology. Necatibey Eğitim Fakültesi Elektronik Fen ve Matematik Eğitimi Dergisi (EFMED), 5(1), 313-329.

Atam, O. \& Tekdal, M. (2010). Fen ve teknoloji dersi 1s1-sıcaklık konusunda hazırlanan simülasyon tabanlı bir yazılımın ilköğretim 5. sınıf öğrencilerinin akademik başarılarına ve aklıcıllğa etkisi. Eğitim Teknolojileri Araştırma Dergisi, 1(2), 1-18.

Aycan, Ş., Arı, E., Türkoğuz, S., Sezer, H. \& Kaynar, Ü. (2002). Fen ve fizik öğretiminde bilgisayar destekli simülasyon tekniğinin öğrenci başarısına etkisi: Yeryüzünde Hareket örneği. M.Ü. Atatürk Ĕgitim Fakültesi Ĕ̈itim Bilimleri Dergisi, 15, 57-70.

Aytaş, G. \& Uysal, B. (2017). Oyun kavramı ve sınıflandırılmasına yönelik bir değerlendirme. Manisa Celal Bayar Üniversitesi Sosyal Bilimler Dergisi, 15(1), 675-690.

Bakaç, M., Kartal-Taşoğlu, A. \& Akbay, T. (2011). The effect of computer assisted instruction with simulation in science and physics activities on the success of student: Electric current. Eurasion Journal of Physics and Chemistry Education. January (special issue), 34-42.

Baltzis, K.B. \& Koukias, K.D. (2009). Using laboratory experiments and circuit simulation IT Tools in an undergraduate course in analog electronics. Journal of Science Education and Technology, 18(6), 546-555.

Bayrak, C. (2008). Effects of computer simulations programs on university students' achievements in physics. Turkish Online Journal of Distance Education (TOJDE), 9(4), 53-62.

Bell, R.L. \& Trundle, K.C. (2008). The use of a computer simulation to promote scientific conceptions of moon phases. Journal of Research in Science Teaching, 45(3), 346-372.

Bozkurt, E. \& Sarıkoç, A. (2008). Fizik eğitiminde sanal laboratuar, geleneksel laboratuarın yerini tutabilir mi?. Selçuk Üniversitesi Ahmet Keleşoğlu Eğitim Fakültesi Dergisi, 25, 89-100. 
Ceylan, E. \& Saygıner, Ş. (2017, 27-28 Ekim). Fen ve matematik eğitiminde geleneksel laboratuvar uygulamalarına bir alternatif: PhET simülasyonlarl. Uluslararası Eğitim Teknolojileri Sempozyumu, Cumhuriyet Üniversitesi, Sivas.

Chang, K.E., Chen, Y.L., Lin, H.Y. \& Sung, Y.T. (2008). Effects of learning support in simulation-based physics learning. Computers \& Education, 51, 1486-1498.

Chen, C.H. \& Howard, B. (2010). Effect of live simulation on middle school students' attitudes and learning toward science. Educational Technology \& Society, 13(1), 133-139.

Coşkun, A. \& Özdemir, M. (2013). "Yeryüzünde Hareket" konusunda bilgisayar destekli eğitimin (ortaöğretim öğrencilerinde) öğrenci başarısına etkisi. Çukurova Üniversitesi Fen ve Mühendislik Bilimleri Dergisi, 29(3), 45-50.

Dağdalan, G. \& Taş, E. (2017). Simülasyon destekli fen öğretiminin öğrencilerin başarısına ve bilgisayar destekli fen öğretimine yönelik tutumlarına etkisi. Fen Bilimleri Öğretimi Dergisi, 5(2), 160-172.

Demirci, N. (2003). Bilgisayarla etkili öğretme stratejileri ve fizik öğretimi (1. Bask1.). Ankara: Nobel Yayıncilik.

Dinçer, S. \& Güçlü, M. (2013, 4-6 Ekim). Fen bilgisi eğitiminde bilgisayar destekli simülasyon kullanımının etkililiği ve yeni yönelimler: Bir meta-analiz çalışması. 6. Uluslararası Bilgisayar ve Öğretim Teknolojileri Sempozyumu, Gaziantep Üniversitesi, Gaziantep.

Emrahoğlu, N. \& Bülbül, O. (2010). 9. sınıf fizik dersi optik ünitesinin bilgisayar destekli öğretiminde kullanılan animasyonların ve simülasyonların akademik başarıya ve akılda kalıcılığa etkisinin incelenmesi. Çukurova Üniversitesi Sosyal Bilimler Enstitüsü Dergisi, 19(3), 409-422.

Engin, A.O., Tösten, R. \& Kaya, M.D. (2010). Bilgisayar destekli eğitim. Sosyal Bilimler Enstitüsü Dergisi, $5,69-80$.

Güneş, B., Ateş, S., Eryılmaz, A., Yürük, N., Özdemir, Ö.F., Kanlı, U., Serin, G., Üstün, U., Aygün, M., Gülçiçek, Ç., Çekiç-Toroslu, S. \& Damlı, V. (2017). Doğru Bilinen Yanlışlardan, Yanlış Bilinen Doğrulara: Fizikte Kavram Yanılgıları. B. Güneş (ed.), Ankara: Palme Yayıncılık.

Hakerem, G., Dobrynina, G. \& Shore, L. (1993, April 15-19). The effect of interactive, three-dimensional, high speed simulations on high school science students' conceptions of the molecular structure of water. Paper presented at the Annual Meeting of the National Association for Research in Science Teaching, Atlanta.

Honey, M.A. \& Hilton, M.L. (2011). Learning science through computer games and simulations. Washington: The National Academies Press.

Huppert, J., Lomask, S.M. \& Lazarowitz, R. (2002). Computer simulations in the high school: Students' cognitive stages, science process skills and academic achievement in microbiology. International Journal of Science Education, 24(8), 803-821.

İlyasoğlu, U. \& Aydın, A. (2014). Doğru akım devreleri konusunun öğretiminde bilgisayar destekli öğretimin fen ve teknoloji öğretmen adaylarının başarısına etkisi, Kastamonu Ĕgitim Dergisi, 22(1), 223-240.

Jaakkola, T. \& Nurmi, S. (2008). Fostering elementary school students' understanding of simple electricity by combining simulation and laboratory activities. Journal of Computer Assisted Learning, 24, 271283. 
Jaakkola, T., Nurmi, S. \& Veermans, K. (2011). A comparison of students' conceptual understanding of electric circuits in simulation only and simulation-laboratory contexts. Journal of Research in Science Teaching, 48(1), 71-93.

Jimoyiannis, A. \& Komis, V. (2001). Computer simulations in physics teaching and learning: A case study on students' understanding of trajectory motion. Computers \& Education, 36, 183-204.

Karal, H., Çebi, A., Pekşen, M. \& Turgut, Y.E. (2010). Sözel problemlerin anlamlandırılması ve çözümünde web tabanlı eğitsel simülasyonların etkisi. Gaziantep Üniversitesi Sosyal Bilimler Dergisi, 9(1), 147162.

Karasar, N. (2004). Bilimsel araştırma yöntemi (13. Baskı). Ankara: Nobel Yayıncılık.

Katırc1, E. \& Satıc1, A.F. (2010). Interactive physics programında simülasyon ve portfolyo uygulamalarının akademik benlik ve yaratıcılık üzerine etkisi. Türk Fen Eğitimi Dergisi, 7(4), 46-59.

Keçeci, G., Kırbağ-Zengin, F. \& Alan, B. (2016a, 6-8 Ekim). Sinir sistemi konusunun simülasyon uygulamalarlyla ögretimi. 4th International Instructional Technologies \& Teacher Education Symposium (ITTES), Frrat Üniversitesi, Elazı ğ.

Keçeci, G., Kırbağ-Zengin, F. \& Alan, B. (2016b, 6-8 Ekim). Simülasyon destekli öğretim tekniğinin fen bilgisi ögretmen adaylarının kas sistemi konusundaki akademik başarllarına ve biyoloji tutumlarına etkisi. 4th International Instructional Technologies \& Teacher Education Symposium (ITTES), Firat Üniversitesi, Elazı̆̆.

Keçeci, G., Yıldız, S. \& Kırbağ-Zengin, F. (2016, 6-8 Ekim). Dengeli beslenme konusunun ilkokul 4. sınıf ögrencilerine simülasyon uygulamalarıyla ögretimi. 4th International Instructional Technologies \& Teacher Education Symposium (ITTES), Firat Üniversitesi, Elazı ğ.

Kert, S.B. \& Tekdal, M. (2008). Alanyazındaki tasarım ilkelerine uygun olarak geliştirilmiş çokluortam ders yazılımının lise düzeyi fizik öğretiminde akademik başarıya ve kalıcılığa etkisi. Pamukkale Üniversitesi Ĕgitim Fakültesi Dergisi, 1(23), 120-131.

Kiboss, J.K., Ndirangu, M. \& Wekesa, E.W. (2004). Effectiveness of a computer-mediated simulations program in school biology on pupils' learning outcomes in cell theory. Journal of Science Education and Technology, 13(2), 207-213.

Korkmaz, A. \& Yıldız, A. (2012). Ortaöğretim okullarında cinsiyet farklılıklarının, fizik dersinde interaktif ve klasik eğitiminde başarısının karşılaştırılması. International Journal of New Trends in Arts, Sports \& Science Education (IJTASE), 1(3), 44-50.

Kör, H., Çataloğlu, E. \& Erbay, H. (2013). Uzaktan ve örgün eğitimin öğrenci başarısı üzerine etkisinin araştırılması. Gaziantep University Journal of Social Sciences, 12(2), 267-279.

Kukkonen, J.E., Kärkkäinen, S., Dillon, P. \& Keinonen, T. (2014). The effects of scaffolded simulationbased inquiry learning on fifth-graders' representations of the greenhouse effect. International Journal of Science Education, 36(3), 406-424.

Kumar, D.D. \& Sherwood, R.D. (2007). Effect of a problem based simulation on the conceptual understanding of undergraduate science education students. Journal of Science Education and Technology, 16(3), 239-246.

Mallick, P.K., Kar, S.K., Mohanty, M.N. \& Kumar, S. (2015). Use of histogram approach in color band detection for electrical passive component. International Journal of Applied Engineering Research, 10(44), 31446-31450. 
Meir, E., Perry, J., Stal, D., Maruca, S. \& Klopfer, E. (2005). How effective are simulated molecular-level experiments for teaching diffusion and osmosis? Cell Biology Education, 4(3), 235-248.

Miles, M.B. \& Huberman, A.M. (1994). Qualitative data analysis. Thousand Oaks, CA: Sage Publication.

Milli Eğitim Bakanlığı (MEB) (2012). Uçak bakım - dirençler ve temel elektrik kanunları, Ankara.

Mitani, Y. \& Hamamoto, Y. (2010, 18-21 August). A study of color features for reading a resistor. SICE Annual Conference, Taipei, Taiwan.

Mosterman, P.J., Campbell, J.O., Brodersen, A.J. \& Bourne, J.R. (1996). Design and implementation of an electronics laboratory simulator. IEEE Transactions on Education, 39(3), 309-313.

Özdener, N. (2005). Deneysel öğretim yöntemlerinde benzetişim (simulation) kullanımı. The Turkish Online Journal of Educational Technology, 4(4), 93-98.

Özer, İ.E., Canbazoğlu-Bilici, S. \& Karahan, E. (2016). Fen bilimleri dersinde algodoo kullanımına yönelik öğrenci görüşleri. Trakya Üniversitesi Eğitim Fakültesi Dergisi, 6(1), 28-40.

Pekdağ, B. (2010). Kimya öğreniminde alternatif yollar: Animasyon, simülasyon, video ve multimedya ile öğrenme. Türk Fen Ĕ̈itimi Dergisi, 7(2), 79-110.

Romero, C. \& Martinez, E. (2012). Simulation-based teaching in a course of fluid mechanics. Paper presented to the 4th International Conference on Education and New Learning Technologies, Barcelona, Spain.

Ronen, M. \& Eliahu, M. (1999). Simulation as a home learning environment - student's views. Journal of Computer Assisted Learning, 15, 258-268.

Ronen, M. \& Eliahu, M. (2000). Simulation - a bridge between theory and reality: The case of electric circuits. Journal of Computer Assisted Learning, 16, 14-26.

Sarabando, C., Cravino, J.P. \& Soares, A.A. (2014). Contribution of a computer simulation to students' learning of the physics conceptss of weight and mass. Procedia Technology, 13, 112-121.

Shaw, E.L. \& Okey, J.R. (1985, April 15-18). Effects of microcomputer simulations on achievement and attitudes of middle school students. 58th Annual Meeting of the National Association for Research in Science Teaching, Indiana.

Squire, K., Barnett, M., Grant, J.M. \& Higginbotham, T. (2004). Electromagnetism supercharged learning physics with digital simulation games. Science Education, 87(2), 1-22.

Stern, L., Barnea, N. \& Shauli, S. (2008). The effect of a computerized simulation on middle school students' understanding of the kinetic molecular theory. Journal of Science Education and Technology, 17(4), 305-315.

Stockley, C., Oxlade, C. \& Wertheim, J. (2016). Şekilli fizik sözlüğ̈̈. (Çev. Sadi Turgut). Ankara: Tübitak Popüler Bilim Kitapları.

Şengel, E., Özden, M.Y. \& Geban, Ö. (2002). Bilgisayar simulasyonlu deneylerin lise ögrrencilerinin yerdeğiştirme ve hız kavramlarını anlamadaki etkisi. V. Ulusal Fen Bilimleri ve Matematik Eğitimi Kongresi, ODTÜ, Ankara.

Şimşek, F. (2017). Fen bilimleri dersinde animasyon ve simülasyon kullanımının öğrencilerin akademik başarısı ve bilgilerin kalıcılığı üzerine etkisi. Uluslararası Ĕ̆itim Bilim ve Teknoloji Dergisi, 3(3), 112-124. 
Tanel, Z. \& Önder, F. (2010). Elektronik laboratuarında bilgisayar simülasyonları kullanımının öğrenci başarısına etkisi: Diyot deneyleri örneği. Dokuz Eylül Üniversitesi Buca Eğitim Fakültesi Dergisi, 27, 101-110.

Taşlıdere, E. (2014). Kavramsal değişim yaklaşımının doğru akım devreleri konusundaki kavram yanılgılarının giderilmesine etkisi. Bartın Üniversitesi Eğitim Fakültesi Dergisi, 3(1), 200-223.

Tekdal, M. (2002). Etkileşimli fizik simülasyonlarının geliştirilmesi ve etkin kullanılması. V. Ulusal Fen bilimleri ve Matematik Eğitimi Kongresi, ODTÜ, Ankara.

Ulukök, Ş., Çelik, H. \& Sarı, U. (2013). Basit elektrik devreleriyle ilgili bilgisayar destekli uygulamaların deneysel süreç becerilerinin gelişimine etkisi. Kuramsal Eğitimbilim Dergisi, 6(1), 77-101.

URL: Direnç Hesaplama Aracı (Uyarlama: Murat Kara), http://ekinoks.cu.edu.tr/direnc/

Uşun, S. (2013). Bilgisayar destekli ögretimin temelleri (3. Baskı). Ankara: Nobel Yayıncılık.

White, B., Kahriman, A., Luberice, L. \& Idleh, F. (2010). Evaluation of software for introducing protein structure: visualization and simulation. Biochemistry and Molecular Biology Education, 38(5), 284289.

Yaman, M. (2005). Farklı öğretici ögelerle desteklenmiş bir simulasyonun öğrenmeye etkisi. Eurasian Journal of Educational Research, 21, 260-272.

Yaman, M. \& Nerdel, C. (2008). Identification of student types based on their knowledge and their interests when learning with computer simulations. Eurasian Journal of Educational Research, 31, 135-150.

Yııdırım, A. \& Şimşek, H. (2011). Sosyal bilimlerde nitel araştırma yöntemleri (8. Baskı). Ankara: Seçkin Yayıncilik.

Yılmaz, M. \& Eren, A. (2014). Sınıf öğretmen adaylarına basit elektrik devreleri konusunun simülasyon ve laboratuvar uygulaması teknikleriyle öğretimi. Trakya Üniversitesi Eğitim Fakültesi Dergisi, 4(2), 84-99.

Yolaş-Kolçak, D., Moğol, S. \& Ünsal, Y. (2014). Fizik öğretiminde kavram yanılgılarının giderilmesine ilişkin laboratuvar yöntemi ile bilgisayar simülasyonlarının etkilerinin karşılaştırılması. Eğitim ve Bilim, 39(175), 154-171.

Zacharia, Z.C. (2005). The impact of interactive computer simulations on the nature and quality of postgraduate science teachers' explanations in physics. International Journal of Science Education, 27(14), 1741-1767.

Zacharia, Z.C. (2007). Comparing and combining real and virtual experimentation: an effort to enhance students' conceptual understanding of electric circuits. Journal of Computer Assisted Learning, 23(2), 120-132. 